\title{
19. MINERALOGY OF FIRM MUDS AND MUDSTONES ASSOCIATED WITH VOLCANOSEDIMENTARY LAYERS FROM THE TYRRHENIAN SEA, HOLES 650A AND 651A, O.D.P. LEG 1071
}

\author{
J. Allouc ${ }^{2}$ and Y. Champetier ${ }^{2}$
}

\begin{abstract}
At Holes 650A and 651A, set respectively in the Marsili Basin and the Vavilov Basin, Pleistocene sediments (turbiditic inputs interbedded with essentially hemipelagic sediments) may show layers of mudrocks with moderate to strong induration. Except in the two samples from Hole 651A, it seems that zeolite crystallization does not play a role in the induration phenomenon. This latter appears to result from in situ clay authigenesis. Secondary $\mathrm{K}-\mathrm{Fe}$ beidellite or Fe- $\mathrm{Mg}$ beidellite form diagenetic growths and bridges between sedimented particles. Turbidites are rich in volcaniclastics (glass, pumices and other volcanogenic elements) but the induration phenomenon appears to be associated essentially with the occurrence of basaltic detritus. It is proposed that clay authigenesis results from low temperature alteration of basaltic fragments issued from Vavilov and probably Marsili seamounts in sediments isolated from seawater by overlying deposits.
\end{abstract}

\section{INTRODUCTION}

The early submarine lithification of pelagic or hemipelagic carbonate muds is a common process in the Mediterranean Sea (Allouc, 1986, and references therein). Diagenetic processes affecting oceanic carbonate sediments during their burial were analyzed in detail in DSDP cores from many sites (synthesis in Garrison, 1981). In the western Mediterranean Sea, the carbonate cementation and recrystallization which starts at about $400 \mathrm{~m}$ below the seafloor was studied by McKenzie et al. (1976) in Site 372 of Leg 42.

By contrast, the diagenetic hardening of essentially silicoaluminous materials buried to no more than a few hundred meters is a process which, until now, has been observed less frequently in marine sediments. Some layers of this nature, interbedded with brownish pelagic clays, were noted in several areas of the Pacific Ocean (Hoffert et al., 1978; Hoffert, 1980, and references therein). In these areas, the hardening results from crystallization of clay minerals and authigenic zeolites derived by alteration of Eocene volcanogenic particles.

In the Mediterranean Sea (Tyrrhenian Sea, Hole 373A, Leg 42), Bernoulli et al. (1978) refer to the occurrence of a foraminiferal sandstone cemented by authigenic phillipsite at a subbottom depth of about $269 \mathrm{~m}$. The neoformation of zeolite was explained by the proximity of an altered basaltic flow (Bernoulli et al., 1978).

But, in this area, evidence of pervasive silicate authigenesis and subsequent hardening of volcanogenic sediments deposited far above the volcanic basement seems not to have been reported until now.

The in situ transformation of pyroclastic sands or volcanic ashes and glasses to zeolites or clays have been described or supported in Quaternary volcanogenic sediments of the Mediterranean Sea (cf., for instance, Müller, 1961; Shumenko and Shimkus, 1979, for zeolites; Norin, 1953; Grim and Vernet, 1961, for clays), but it was later established that these kinds of transformation were not common in this area (Chamley and Giroud

\footnotetext{
${ }^{1}$ Kastens. K. A., Mascle, J., et al., 1990. Proc. ODP, Sci. Results, 107: College Station, TX (Ocean Drilling Program).

${ }^{2}$ Laboratoire Sédimentologie-Substances utiles et énergétiques E.N.S.G., B.P. 452, 54001 NANCY Cedex (France).
}

d'Argoud, 1978). Thus, indurated sediments from Holes 650A and $651 \mathrm{~A}$ appear as a rather unusual occurrence in the Mediterranean Sea sedimentary environment. Their study yields complementary information concerning the susceptibility of volcaniclastic grains to alteration and to the process of early diagenesis leading to induration in mostly noncarbonated deposits.

\section{SEDIMENTARY ENVIRONMENT AND MATERIAL}

In the intervals where samples from Holes $650 \mathrm{~A}$ and $651 \mathrm{~A}$ were taken, sediments consist mostly of turbidites rich in coarse or medium volcanogenic detritus (gravel to silt) interbedded with volumetrically subordinate muds (often calcareous muds) interpreted as hemipelagic deposits.

Ten samples were taken from Core $18 \mathrm{X}$ (Sections 1 and 2) and Core $43 \mathrm{X}$ (Section 1) of Hole 650A situated approximately in the center of the Marsili Basin, about $45 \mathrm{~km}$ northeast of the Marsili seamount. According to Shipboard Studies (Kastens, Mascle, et al., 1987), the samples are Pleistocene (Nannozones NN19 and NN20).

Lithologic descriptions (Kastens, Mascle, et al., 1987) give the following information:

1. Sediments of Core $18 \mathrm{X}$ belong to an interval showing alternations of graded sand and silt containing variable finegrained volcaniclastic particles (volcanic glass and pumices, composition not given) and homogeneous calcareous muds $(10 \%-$ $20 \% \mathrm{CaCO}_{3}$ ); calcareous muds are dominant. Indurated sediments consist only of some calcareous mudstone layers, which are some centimeters thick;

2. Sediments of Core $43 \mathrm{X}$ are made up mainly of calcareous muds (mean $\mathrm{CaCO}_{3} 15 \%-20 \%$ ). They belong to an interval where clastic layers are less frequent than in the previous one. However, percentages of fine-grained vitric particles remain approximately the same (about $5 \%$ after smear slide observations). Indurated material occurs as small pieces of drilling biscuit.

One sample was taken from Core $11 \mathrm{R}$ (Section 3) and another from Core 12R (Section 1) of Hole 651A set above a basement ridge marking the axis of the Vavilov Basin at about 35 $\mathrm{km}$ north of the Vavilov seamount. According to shipboard studies (Kastens, Mascle, et al., 1987), layers of indurated clay and mudstone from Cores 11R and 12R are Pleistocene (Nannozone NN21) but a piece of indurated clay from the Core $12 R$ was 
dated as late Pliocene on the basis of its nannofossil content; it was not sampled for this study. that:

The drilling results (Kastens, Mascle, et al., 1987) indicate

1. Sediments of Core $11 \mathrm{R}$ consist mostly of nearly homogeneous sand of pyroclastic origin, together with coarser volcanogenic detritus (composition not given). There is only some occurrence of mudrocks: small pieces of mud or mudstone and a 3-cm-thick mudstone layer, from which a sample was taken;

2. Sediments of Core $12 \mathrm{R}$ show a succession of three graded units composed of coarse siliciclastic facies (indurated breccia and sand with gravel). These coarse-grained facies, components of which indicate an essentially extrusive igneous origin, pass upward into clays and mudstones containing some scattered volcanogenic fragments (see "Bulk Composition and S.E.M. Observations" below).

Figure 1 gives the bulk mineralogy of the samples. Samples from Cores $18 \mathrm{X}$ and $43 \mathrm{X}$ of Hole $650 \mathrm{~A}$ correspond essentially to grey muds or grey calcareous muds. However, Sample $650 \mathrm{~A}$ $18 \mathrm{X}-1,95-96 \mathrm{~cm}$, contains about $25 \%$ sand and about $60 \%$ silt; it is classified as a sandy silt. Dried up Samples 650A-18X-1, 96$97 \mathrm{~cm}$, and $650 \mathrm{~A}-18 \mathrm{X}-2,149-150 \mathrm{~cm}$, show a weak cohesion, they are easily crumbled with the fingers and disintegrate in water. Only Samples $650 \mathrm{~A}-18 \mathrm{X}-1,9-10 \mathrm{~cm}$, and $650 \mathrm{~A}-43 \mathrm{X}-1,3-5$ $\mathrm{cm}$, are really indurated and keep their cohesion in water. According to Rabinowitz et al. (1985), they are classified as firm muds.

Sample 651A-11R-3, 132-135 cm, shows two parts separated by a sharp contact:

1. The lower part consists of a very indurated olive grey mudstone noted $651 \mathrm{~A}-11 \mathrm{R}-3,132-135 \mathrm{~cm}$;

2. The upper part consists of a cohesive grey sandstone mainly composed of variable volcanogenic fragments (see "Results, Site 651A" below). It is noted 651A-11R-3, 132-135 cm. Sample $651 \mathrm{~A}-12 \mathrm{R}-1,16-19 \mathrm{~cm}$, is a very indurated olive-grey to greyish-green mudstone.

\section{METHODS}

In order to eliminate seawater salts before the mineralogical and chemical analyses, the samples were washed in demineralized water. After which, they were crushed in an agate mortar and a portion of each was decarbonated at a constant $\mathrm{pH} 3$ with $\mathrm{HCl}$ R.P., $1.5 \mathrm{~N}$. For the very indurated mudstone from Hole $651 \mathrm{~A}$, an ultrasonic disaggregation was also necessary. Then, $\mathrm{Ca}, \mathrm{Fe}, \mathrm{Al}$, and $\mathrm{K}$ were measured in the centrifuged supernatant by atomic absorption spectrometry, in order to estimate the calcium carbonate percentage and to control the effect of the $\mathrm{HCl}$ etching on insoluble residue.

After washing and setting in a stable suspension by resin $\mathrm{Na}^{+}$(cf. Rouiller et al., 1984 and references therein), the clay fraction $<2 \mu \mathrm{m}$ was separated by successive siphoning. For special mineralogical investigations, a separation at $1 \mu \mathrm{m}$ or $0.5 \mu \mathrm{m}$ was carried out on the same samples by ultracentrifugation (Rouiller et al., 1984).

The mineralogical composition of bulk sediments, carbonate-free sediments, and clay minerals was determined by X.R.D. (Co or $\mathrm{Cu}$ target, $1^{\circ} \theta / \mathrm{mn}$ or $1^{\circ} 2 \theta / \mathrm{mn}$ ). A special investigation at $1^{\circ} 2 \theta / 4 \mathrm{mn}$ was operated in the calcite peak (104) field for $\mathrm{Mg}$-calcite detection.

For the bulk mineralogy we have adopted the method discussed by Mann and Müller (1979). The height of typical peaks (at $4.26 \AA$ for the quartz, 3.15-3.21 $\AA$ for the feldspars, $3.03 \AA$ for the calcite, and 4.07 or $2.71 \AA$ for the phillipsite) is multiplied by $4,2,1.5$, and 2 , respectively, and then added to $100 \%$. Moreover, calcite percentage (deduced from chemical analyses), served as a rough internal standard. Semiquantitative estimation of the relative amounts of plagioclase and K-feldspar was performed by comparing the peak height at $3.20 \AA$ (pl) with the one at $3.24-3.25 \AA(\mathrm{Kf})$.

After removing free iron by a buffered dithionite-citrate system (cf. below: selective extraction), mineralogical characteristics of the clay frac- tion were determined by various treatments using the oriented paste method (normal, glycol, or ethylene glycol, heating, hydrazine). The relative abundance of illite, kaolinite, smectites, and mixed-layers was calculated according to the method given by Chamley (1969). The chlorite/ kaolinite weight ratio was deduced from Elverhøi and Rønningsland's graph (1975). Smectites have been characterized according to their d(060) lattice dimension (Brown, 1963; Desprairies, 1951; Chamley et al., 1955) and the test proposed by Greene-Kelly (1953).

The infrared absorption spectrometry was performed with a double beam system on a BECKMAN 42.50 spectrometer over the $4000-200$ $\mathrm{cm}^{-1}$. Samples were dehydrated at ambient temperature (depression of $76 \mathrm{~mm} \mathrm{Hg}$ ) or dried at $110^{\circ} \mathrm{C}$ over a period of $24 \mathrm{hr}$. Pressed discs at 10 metric tons with $1 \mathrm{mg}$ or $0.5 \mathrm{mg}$ sample $/ 300 \mathrm{mg} \mathrm{KBr}$ were used.

Chemical analyses of bulk samples and of carbonate-free $\langle 1 \mu \mathrm{m}$ or $0.5 \mu \mathrm{m}$ fractions were carried out by atomic absorption spectrometry titration, after fusion with strontium metaborate (Jeanroy, 1972).

Selective chemical extractions were made on the bulk insoluble residue or on the clay fraction of carbonate-free samples:

1. By the citrate-bicarbonate $\mathrm{Na}+$ dithionite $\mathrm{Na}$ reagent at $\mathrm{pH} 7$ (Mehra and Jackson, 1960) in order to estimate the proportion of free $\mathrm{Fe}$ (not engaged in a silica lattice).

2. By the oxalic acid + ammonium oxalate reagent at $\mathrm{pH} 3$ (Tamm in Schwertmann, 1964) in order to extract amorphous or weakly crystallized forms of Fe (Jeanroy, 1953). Moreover, amorphous silicates and aluminosilicates are sensitive to this reagent. For instance, it extracts large amounts of amorphous silica and alumina from volcanic ash soils (Fey and Leroux, 1975).

$\mathrm{Si}, \mathrm{Al}, \mathrm{Fe}$, and $\mathrm{K}$ obtained by this method were analyzed by atomic absorption spectrometry.

Semiquantitative microchemical analyses were performed by energydispersive spectrometry (E.D.S.). The microprobe PGT system 3 (Si, Li) was coupled with the S.E.M. (CAMBRIDGE S 250), and the microprobe TRACOR TN 2000 with the T.E.M. (JEOL 200 CX). The accelerating voltage was $10-15 \mathrm{Kv}$ for the first case and $200 \mathrm{Kv}$ for the second case.

Quantitative microchemical analyses were carried out on wavelength dispersive spectrometers (W.D.S.):

1. CAMECA MBX (15 Kv): Analyses on thin section, for data on silt or arenite-sized elements.

2. CAMECA SX $50(15 \mathrm{Kv})$ : Analyses on particles scattered on a carbon stand, for data on clay-sized particles.

$\mathrm{C}_{\text {or. }}$ and $\mathrm{N}$ were analyzed by a "Total Analyzer CHN" CARLO ERBA. In this system, the combustion with $\mathrm{O}_{2}$ was followed by a moderate reduction in order to obtain $\mathrm{N}_{2}$ without reduction of $\mathrm{CO}_{2}$. The gases produced were separated by chromatography and quantified by a Wheatstone microbridge.

\section{RESULTS}

\section{Site 650A}

\section{Bulk Composition and S.E.M. Observations}

The bulk mineralogy of samples is given in Figure 1. Samples (650A-15X-1, $95-96 \mathrm{~cm}$, excepted) contain about $40 \%-55 \%$ clay minerals, $10 \%-25 \%$ quartz, $10 \%-20 \%$ feldspars (mainly plagioclases) and 10\%-20\% calcite. The remainder, representing at most about $10 \%$ of the bulk sediment, consists of dolomite, micas, various ferromagnesian minerals (amphiboles and some pyroxenes), variable silt-sized or barely sand-sized volcanogenic fragments and, in some cases, unidentified zeolites. Volcaniclastics consist mainly of ash and glass with a fresh appearance (with few or without dissolution pits) but there are also some more or less altered unidentifiable lava detritus and scarce yellow glassy silt-sized particles resembling palagonite.

Like the feldspar/quartz ratio, the clay content in firm muds (Samples 650A-15X-1, 95-96 cm; 650A-43X-1, 3-5 cm) appears slightly higher than in the soft muds. These results are in agreement with their respective $\mathrm{SiO}_{2}, \mathrm{Al}_{2} \mathrm{O}_{3}, \mathrm{CaO}$, and $\mathrm{K}_{2} \mathrm{O}$ contents 

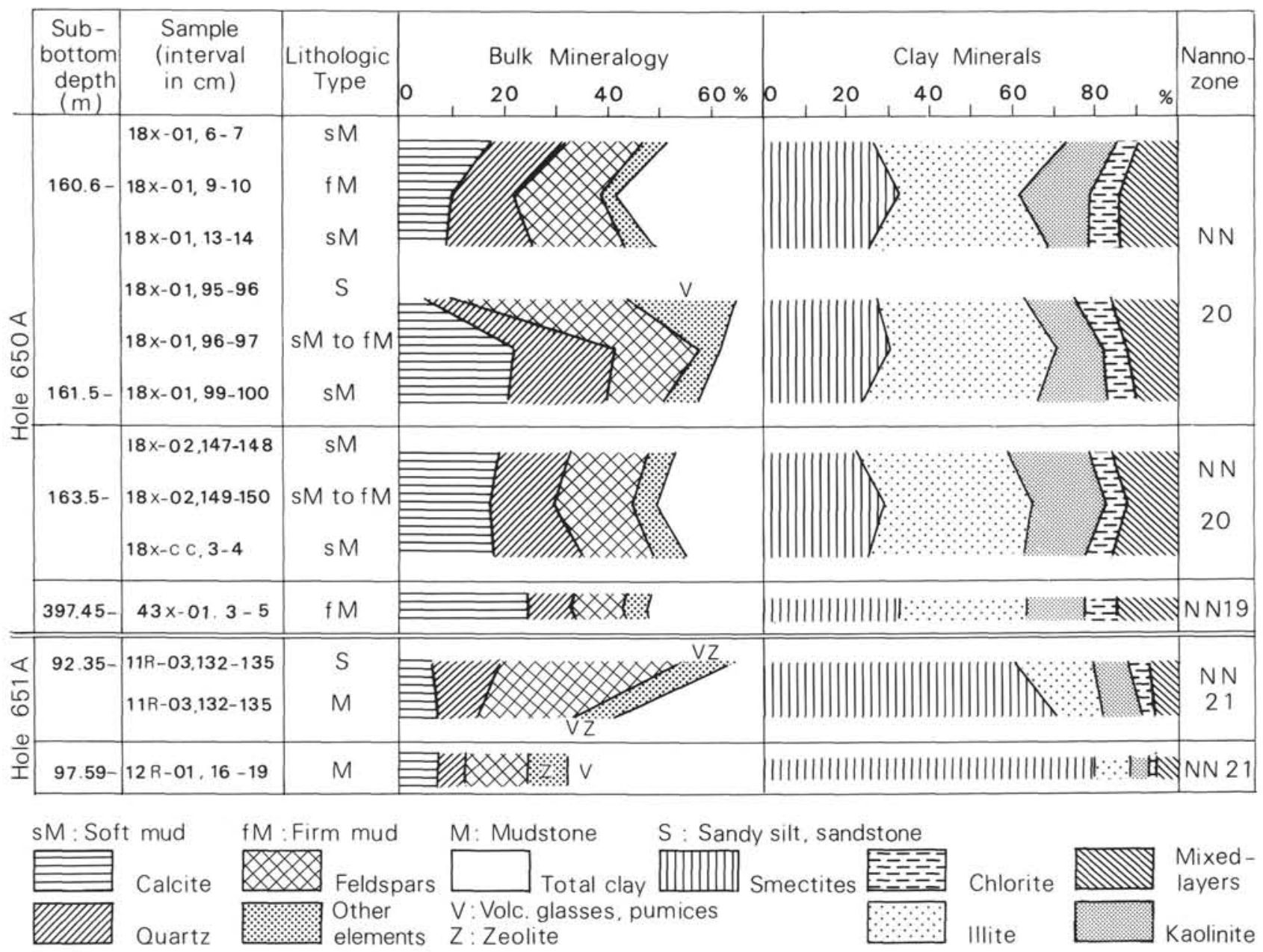

Figure 1. Bulk mineralogical composition of sediments at Holes $650 \mathrm{~A}$ and $651 \mathrm{~A}$.

(Table 1). As indicated by selective extractions, the contents of amorphous silicate or aluminosilicates is very low or nil. The free iron is generally less than $1 \%$ and $\mathrm{C}_{\text {org }}$ less than $0.4 \%$ of the carbonate-free sediment (Tables 1 and 2).

Observations on thin sections show that there is no mineral pore-filling in the chambers of foraminifera. SEM investigations show that the clay assemblage of firm muds contains numerous gently folded layers, with secondary growths that resemble tiny bulges, papilla, or "bacteria" (Figs. 2-3, Plate 1). According to the semiquantitative E.D.S. analyses on the biggest secondary growths (Fig. 2) and also to the very low percentages of organic carbon and amorphous aluminosilicates in these sediments (Tables 1 and 2), these shapes, very probably, correspond to a clay mineral. This type of clay particle is less frequent in the soft muds and, in particular, the secondary growths are much less abundant (Fig. 1, Plate 1).

Sample 650 A-15X-1, $95-96 \mathrm{~cm}$, is clearly different from other samples from Hole $650 \mathrm{~A}$. The content of carbonates $(3 \%)$ and of clay minerals (about $35 \%$ ) are lower, but the feldspar content is high $(35 \%-40 \%)$ with a predominance of unzoned plagioclase with a composition close to andesine. Furthermore, this sample contains about $20 \%$ pyroclastic material. There are numerous glass fragments with both splintered and fibrous forms containing gas tubes suggesting an airborne cooling (Fig. 4, Plate 1). There is no evidence of a diagenetic alteration to clays. Some electron microprobe runs of these volcanic glasses yield the following results (Table 3). According to the $\mathrm{SiO}_{2}$ and $\mathrm{Al}_{2} \mathrm{O}_{3}$ contents (McBirney, 1984) or the $\mathrm{SiO}_{2} \%,\left(\mathrm{~K}_{2} \mathrm{O}+\mathrm{Na}_{2} \mathrm{O}\right) \%$ in
Zanettin's diagram (1984), these glasses have an andesitic to dacitic composition.

\section{Clay Mineralogy}

The clay mineral assemblage contains illite $(30 \%-45 \%)$, kaolinite + chlorite $(15 \%-25 \%)$, and smectite $(20 \%-30 \%)$ (Figs. 1 and 3 ). Generally chlorite is more abundant than kaolinite, but the amount of kaolinite increases with the silt content. The two minerals are represented in roughly equal amounts in Samples $650 \mathrm{~A}-15 \mathrm{X}-1,13-14 \mathrm{~cm}$, and $650 \mathrm{~A}-15 \mathrm{X}-1,65-96 \mathrm{~cm}$. The clay fraction of firm muds is composed of the same species as in soft muds, but the relative proportions are slightly different. In particular, the percentage of smectites is about $5 \%-10 \%$ higher (Figs. 1 and 3).

The v/p Biscaye's Index (1965) is low or negative, indicating "badly crystallized" smectites (Thorez, 1976), with disorders in the stacking of the layers. The diffraction bands between $14 \AA$ and 17-18 $\AA$ after glycolation and between $10 \AA$ and $14 \AA$ after heating at $490^{\circ} \mathrm{C}$ (Fig. 2) mark the occurrence of interstratified structures of $\left(14_{\mathrm{c}}-14_{\mathrm{Sm}}\right)$ type. In addition, after glycolation, a little shoulder on the peak at $10 \AA$ on the side toward lower $2 \theta$ values suggests the presence of $\left(10-14_{\mathrm{Sm}}\right)$ type mixed-layers. The content of these interstratified structures is about $10 \%-15 \%$ of the clay mineral assemblage.

For the firm muds, the $\mathrm{d}(060)$ at about $1.50 \AA$ indicates the occurrence of dioctahedral smectites (Brown, 1963; Desprairies, 1983). After Li saturation and heating at $250^{\circ} \mathrm{C}$, the shift of the (001) reflection to $18 \AA$ confirms that beidellite is the main com- 
Table 1. Chemical composition of bulk samples; oxides (wt $\%), \mathbf{C}$, and $\mathbf{N}(\mathbf{w t} \%)$.

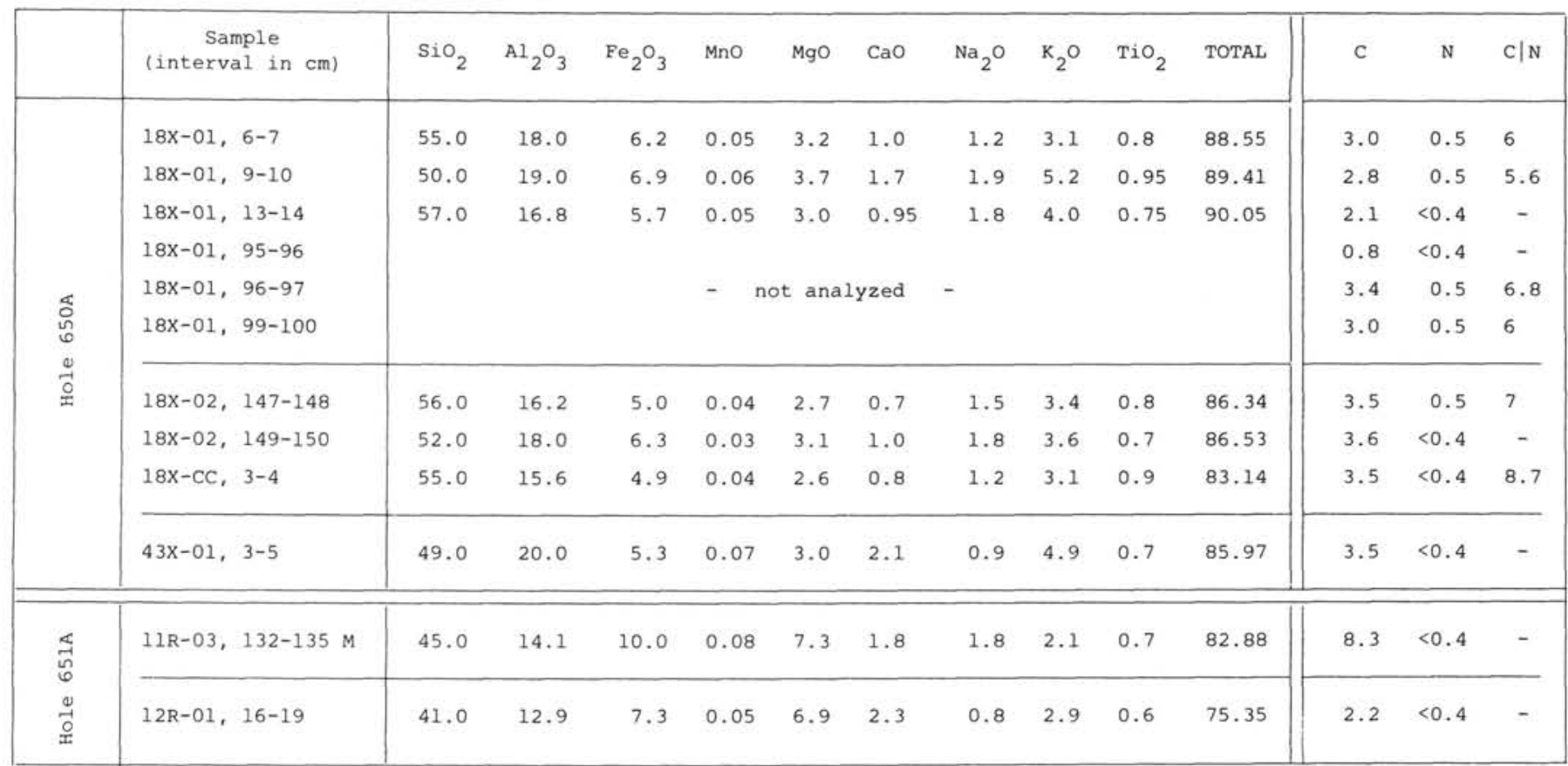

Table 2. Selective extraction analyses. Data (wt $\%$ ) related to the carbonate-free sediment. $\mathrm{A}=$ cold $\mathrm{HCl}$ reagent $(\mathrm{pH} 3)$; $\mathrm{B}=$ citrate, bicarbonate, dithionate reagent $(\mathrm{pH} \mathrm{7)} ; \mathrm{C}=$ acid ammonium oxalate reagent $(\mathrm{pH} \mathrm{3})$.

\begin{tabular}{|c|c|c|c|c|c|c|c|c|c|c|c|c|}
\hline & Sample & & $\mathrm{Si}$ & ---- & & Al & & & $\mathrm{Fe}$ & & & K \\
\hline & (interval in $\mathrm{cm}$ ) & A & B & C & A & B & C & A & B & C & A & $\mathrm{C}$ \\
\hline \multirow{10}{*}{ 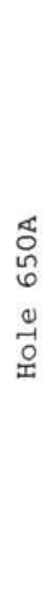 } & $18 x-01,6-7$ & 1.3 & 3.4 & 0.5 & 0.8 & 0.9 & 1.2 & 0.8 & 6.9 & 2.0 & 2.0 & 1.9 \\
\hline & $18 x-01,9-10$ & 0.9 & 3.8 & 0.4 & 0.9 & 1.5 & 2.7 & 0.5 & 9.2 & 2.8 & 2.2 & 4.1 \\
\hline & $18 x-01,13-14$ & 1.3 & 2.5 & 0.5 & 1.6 & 1.3 & 2.0 & 0.6 & 6.8 & 1.5 & 2.4 & 1.7 \\
\hline & $18 x-01,95-96$ & 2.1 & 5.8 & 0.2 & 2.6 & 3.8 & 4.7 & 0.9 & 5.2 & 1.3 & 0.5 & 3.2 \\
\hline & $18 x-01,96-97$ & 1.3 & 1.8 & 0.9 & 1.1 & 1.3 & 2.5 & 0.6 & 5.9 & 2.6 & 2.5 & 5.6 \\
\hline & $18 x-01,99-100$ & 1.2 & 3.0 & 0.6 & 1.1 & 1.0 & 1.5 & 0.9 & 9.1 & 3.1 & 2.2 & 2.1 \\
\hline & $18 x-02,147-148$ & 1.6 & 3.3 & 0.4 & 2.8 & 1.8 & 3.0 & 0.6 & 6.4 & 2.6 & 3.8 & 7.3 \\
\hline & $18 x-02,149-150$ & 1.1 & 3.1 & 0.8 & 4.5 & 1.2 & 3.6 & 1.1 & 5.6 & 1.8 & 5.1 & 8.8 \\
\hline & $18 \mathrm{x}-\mathrm{CC}, \quad 3-4$ & 1.2 & 4.2 & 0.5 & 2.0 & 1.6 & 2.5 & 0.8 & 8.0 & 3.7 & 3.3 & 4.6 \\
\hline & $43 x-01,3-5$ & 1.3 & 3.7 & 1.2 & 1.3 & 1.2 & 2.8 & 1.3 & 8.0 & 3.4 & 2.4 & 6.9 \\
\hline 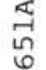 & $11 \mathrm{R}-03,132-135 \mathrm{M}$ & 1.9 & 5.2 & 1.3 & 4.3 & 2.9 & 9.0 & 1.6 & 6.8 & 5.8 & 5.6 & 18.4 \\
\hline -1 & $12 \mathrm{R}-01,16-19$ & 2.3 & 6.0 & 2.9 & 1.9 & 3.9 & 9.3 & 1.9 & 12.0 & 10.2 & 3.0 & 16.1 \\
\hline
\end{tabular}




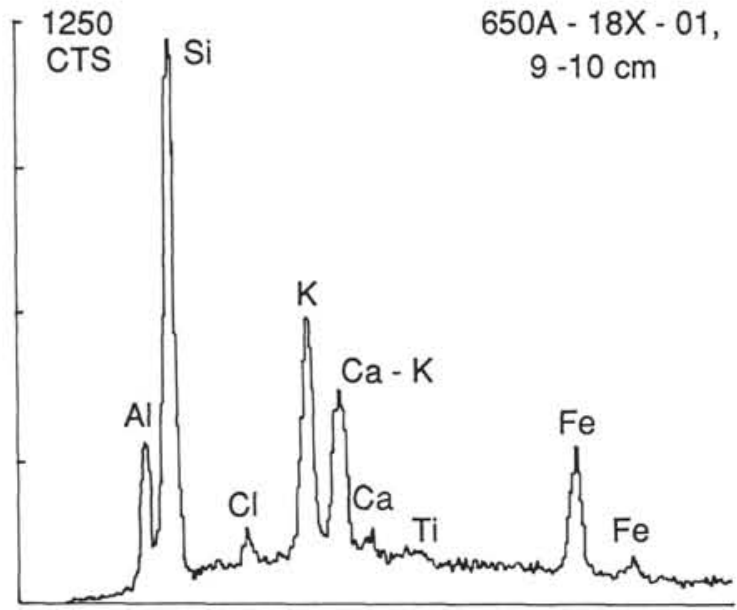

Figure 2. EDS analysis of secondary growth on a clay particle. Firm mud.

Table 3. Chemical composition (\%) of volcanic glasses (Sample 650A$18 X-1,95-96 \mathrm{~cm})$.

\begin{tabular}{|c|c|c|c|c|c|}
\hline Run & 19 & 20 & 21 & 22 & 23 \\
\hline $\mathrm{SiO}_{2}$ & 56.05 & 62.37 & 63.14 & 63.94 & 61.23 \\
\hline $\mathrm{A}_{2}{ }_{2} \mathrm{O}_{3}$ & 14.57 & 15.83 & 17.34 & 15.33 & 18.48 \\
\hline $\mathrm{Fe}_{2} \mathrm{O}_{3}$ & 9.93 & 6.38 & 4.55 & 6.67 & 5.43 \\
\hline Mno & .25 & .17 & .06 & .13 & .13 \\
\hline MgO & 8.53 & 1.18 & .99 & 1.64 & 1.05 \\
\hline $\mathrm{CaO}$ & 7.41 & 4.77 & 5.51 & 4.69 & 6.45 \\
\hline $\mathrm{Na}_{2} \mathrm{O}$ & 2.01 & 2.98 & 3.88 & 2.51 & 3.43 \\
\hline $\mathrm{K}_{2} \mathrm{O}$ & .99 & 2.76 & 2.28 & 2.85 & 1.93 \\
\hline $\mathrm{TiO}_{2}$ & .67 & .83 & .55 & .72 & .58 \\
\hline Total & 100.41 & 97.27 & 98.30 & 98.48 & 98.71 \\
\hline
\end{tabular}

ponent of the "swelling complex" (Fig. 4). According to chemical analyses of the fraction below $0.5 \mu \mathrm{m}$ and data obtained by W.D.S. microprobe analyses on dispersed particles (Table 4), it is a potassic ferriferous beidellite, with some $\mathrm{Mg}$ in the octahedral position.

The high proportion of exchangeable interlayer potassium in smectites of the firm muds is substantiated by the quantities of this element extracted by the acid ammonium oxalate reagent (Table 2). Beidellites of this type have been described by Desprairies (1981) and Parra et al. (1985).

Montmorillonite must constitute only a small percentage of the smectite because it was not possible to detect a significant shift to $10 \AA$ of the (001) reflection after the Greene-Kelly's test (Fig. 4).

Transmission electron microscope investigations on the firm muds clay fraction show the presence of some "opaque smectites" or "folded smectites" almost identical to those recognized by Hoffert (1980) and Chamley et al. (1985) (Fig. 6, Plate 1). According to these authors it is indicative of the alteration of volcanogenic material, particularly basalts (Hoffert, 1980). The "folded smectites" are less abundant in the soft mud where smectites essentially correspond to the "fleecy smectites" morphological type of Chamley et al. (1985) (Fig. 5, Plate 1).

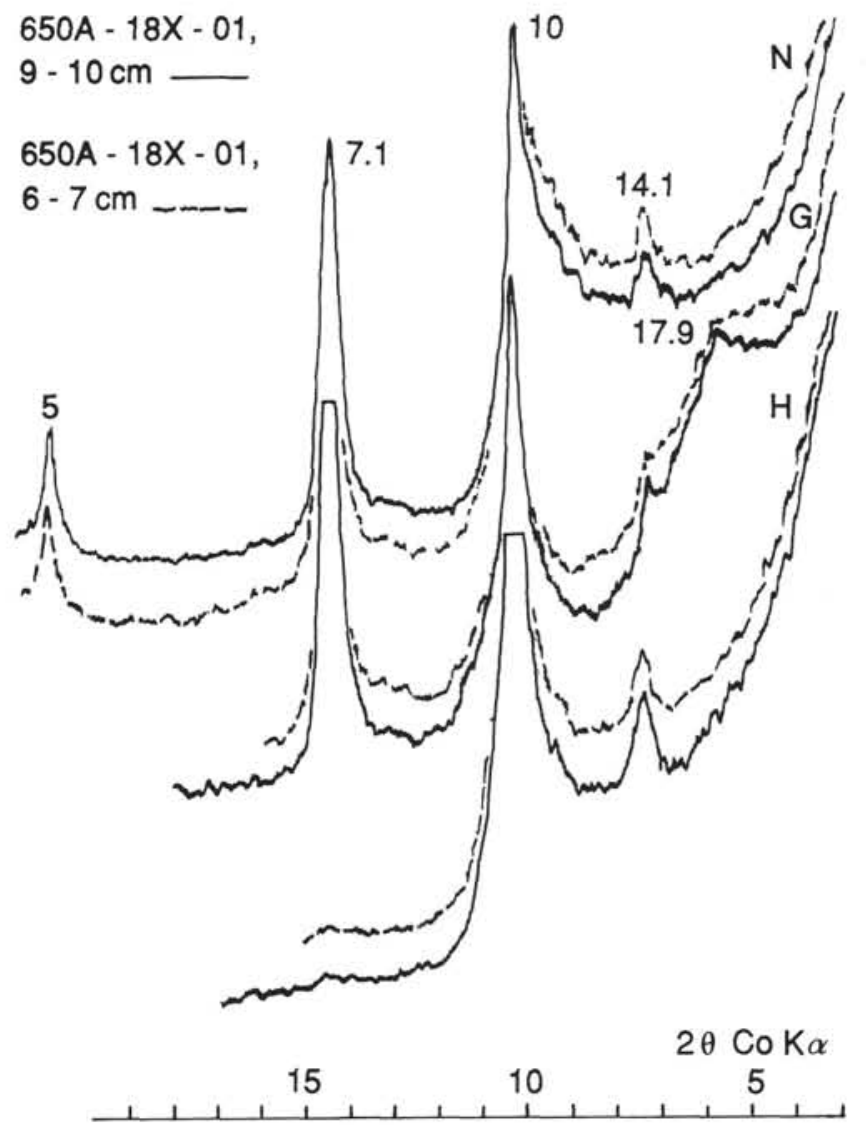

Figure 3. XR-diagrams. Soft mud (broken line) and firm mud (solid line). $<2-\mu \mathrm{m}$ fraction.

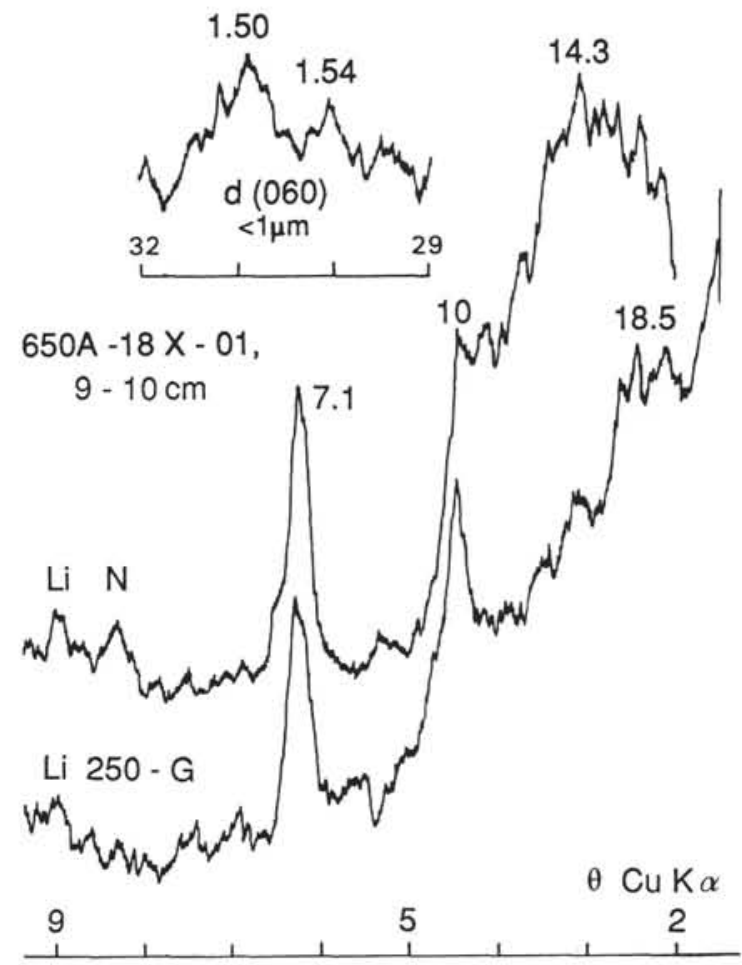

Figure 4. XR-diagrams. Clay fraction of a firm mud. Greene-Kelly's test and $d(060)$ lattice dimension. 
Table 4. Chemical composition (\%) of smectites at Hole $650 \mathrm{~A}$. Comparison with K-Fe beidellites of the northeast Atlantic. (Calculated data for anhydrous composition, $10 \%-15 \% \mathbf{H}_{2} \mathbf{O}$.)

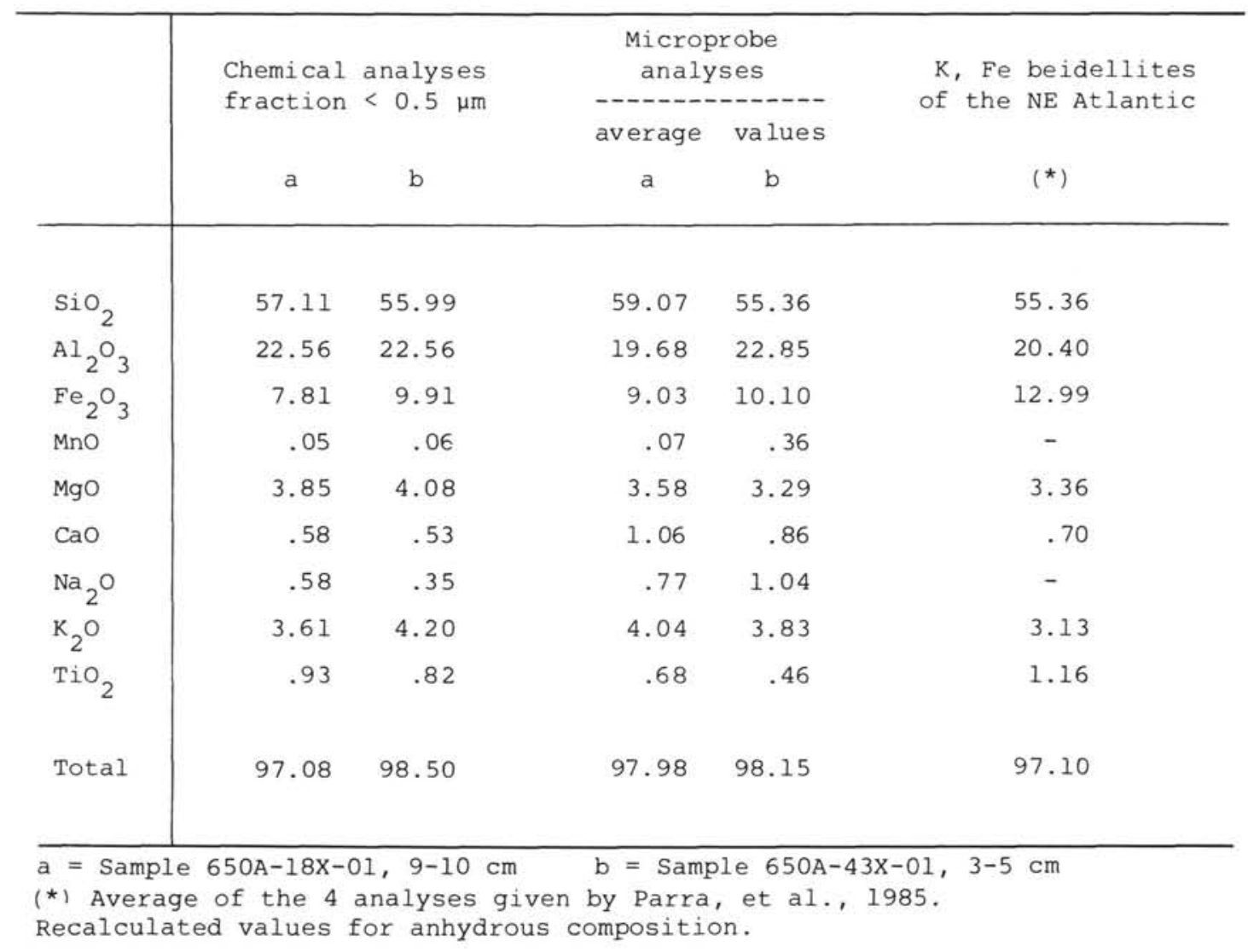

To summarize, most smectites are potassic ferriferous beidellite, morphological types of which essentially correspond to "fleecy smectites" but firm muds also show "folded smectites" and "opaque smectites." The exact composition of secondary growths could not be determined, but they certainly also correspond to a beidellite mineral type.

\section{Site 651A}

\section{Bulk Composition and S.E.M. Observations}

\section{Mudstones}

The bulk mineralogy of samples is given in Figure 1. The mudstones $651 \mathrm{~A}-11 \mathrm{R}-3,132-135 \mathrm{~cm}$, and 651A-12R-1, 16-19 $\mathrm{cm}$, contain about $60 \%-70 \%$ clay minerals, $10 \%-15 \%$ feldspars (mainly plagioclase), $5 \%-7 \%$ calcite, and a few percent quartz and zeolite. Observation of thin sections shows that zeolite crystals are mainly localized inside intra-element spaces such as chambers of foraminifera (Fig. 9, Plate 2). They also may occur as a rim surrounding detrital grains but never build a network of crystals throughout the mudrock. Despite the fact that detrital grains are microscopically difficult to recognize, because of their very fine grain size, these mudstones also contain some fragments of basaltic lavas and grains of yellowish glass (probably palagonite). These particles were better observed in the silty sandstone facies (Sample 651A-11R-3, 132-135 cm, Fig. 8, Plate 2).

The selective extraction by the acid ammonium oxalate reagent points to the very low content of amorphous aluminosilicate compounds and the free iron extracted by the citrate-bicarbonate-dithionite reagent is, at best, around $1 \%$ (Table 2). The organic matter is lower than $1 \%$ (Table 1).
The scanning electron microscope observations of these samples show two microfacies. Sample 651A-11R-3, 132-135 cm, appears to be mainly made up of joined folded sheets with very numerous secondary growths similar to those described for the firm muds from Hole 650A (fine bulges, "papilla," or "bacteria"-like particles) (Figs. 11, 12, Plate 2). As these samples do not contain amorphous material, these silico-aluminous secondary growths (Fig. 5) also correspond to a clay mineral. They can grow on any substrate, in particular on detrital grains (Fig. 12, Plate 2), or coccoliths (Fig. 13, Plate 3). In this way, clay miner-

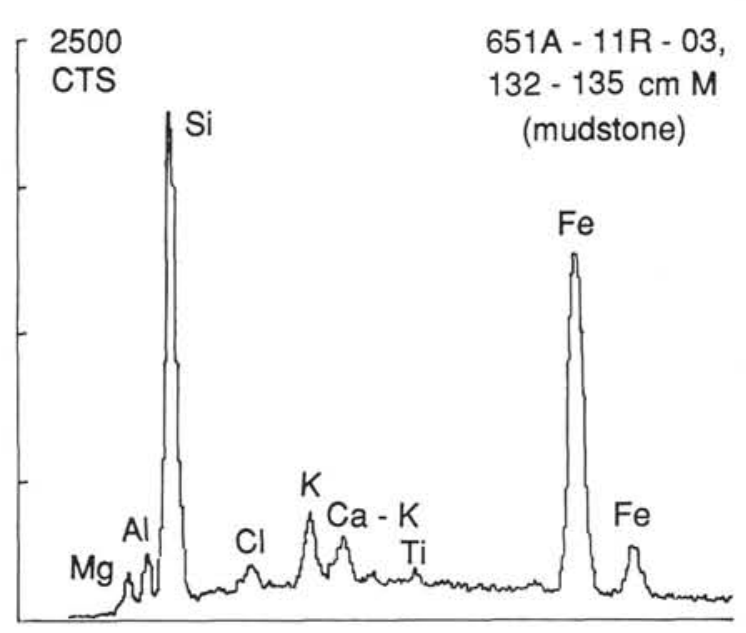

Figure 5. EDS analysis of authigenic clay particle. Mudstone. 
als build a frame of diagenetic bridges. In Sample 651A-12R-1, $16-19 \mathrm{~cm}$, clays make a densely packed mass that almost completely conceals detrital or biogenic components (Fig. 14, Plate 3 ). This mass is organized in aggregated clusters of coalescent particles from 0.3 to $0.8 \mu \mathrm{m}$ in length (Fig. 15, Plate 3). Each particle resembles those of secondary growths seen in indurated sediments of Hole $650 \mathrm{~A}$ and identical shapes are visible in places (Fig. 16, Plate 3).

\section{Silty Sandstone}

In the silty sandstone (Sample 651A-11R-3, 132-135 cm) which overlays the mudstone (Sample 651A-11R-3, 132-135 cm), clays do not represent more than $35 \%$ of the bulk sediment. The detrital grains, several millimeters in length, consist mainly of numerous fresh potassic feldspars together with rather fresh plagioclases (with a composition of andesine to labradorite) and fragments of basic lavas in variable states of alteration. Analyses of feldspathic microlites on the less altered basaltic clasts indicate a labradorite composition (Table 5). Additionally, scattered in the rock, there are altered yellowish to brownish glass fragments, vesicular in places (Fig. 8, Plate 2) resembling palagonitized clasts (cf. Bernoulli et al., 1978); some mafic minerals (particularly pyroxenes) are also visible.

In addition, this sample contains numerous crystals of phillipsite in rosettes or bundles which form a rim around volcanogenic grains (Figs. 9 and 10, Plate 2). Clay minerals show the same morphological characteristics as those of the underlying mudstone (joined and folded particles with secondary growths).

\section{Clay Mineralogy of Mudstones}

The clay fraction of the two mudstones 651A-11R-3, 132-135 $\mathrm{cm}$, and $651 \mathrm{~A}-12 \mathrm{R}-1,16-19 \mathrm{~cm}$, have approximately the same composition; it consists of about $5 \%-10 \%$ chlorite + kaolinite, about $10 \%$ illite and about $70 \%-80 \%$ smectites (Figs. 1 and 6 ). The "swelling complex" proportion is therefore much larger than in firm muds from Hole 650A. The $\mathrm{v} / \mathrm{p}$ Biscaye's index close to 0.3 marks a rather poorly crystallized structure.

All the layers expand to $17-18 \AA$ (Fig. 7). Thus, according to the Greene-Kelly's test, there is no montmorillonite. The XR diagrams show two more or less weakly defined $\mathrm{d}(060)$ peaks at about $1.505 \AA$ and $1.52-1.525 \AA$. The peak near $1.52 \AA$ may in-

Table 5. Microanalyses of plagioclases (Sample 651A-11R-3, 132-135 $\mathrm{cm}$, sandstone part).

\begin{tabular}{|c|c|c|c|c|}
\hline Run & 32 & 33 & 34 & 22 \\
\hline $\mathrm{SiO}_{2}$ & 48.00 & 49.52 & 48.05 & 50.00 \\
\hline $\mathrm{Al}_{2} \mathrm{O}_{3}$ & 31.85 & 31.07 & 32.17 & 30.90 \\
\hline $\mathrm{Fe}_{2} \mathrm{O}_{3}$ & .60 & .47 & .52 & .87 \\
\hline $\mathrm{MnO}$ & .01 & .08 & .05 & .04 \\
\hline $\mathrm{MgO}$ & .03 & .01 & .01 & .12 \\
\hline $\mathrm{CaO}$ & 15.29 & 14.62 & 15.32 & 14.17 \\
\hline $\mathrm{Na}_{2} \mathrm{O}$ & 2.54 & 2.84 & 2.36 & 2.75 \\
\hline $\mathrm{K}_{2} \mathrm{O}$ & .83 & .31 & .40 & .55 \\
\hline $\mathrm{TiO}_{2}$ & .01 & .01 & .01 & .03 \\
\hline Total & 99.16 & 98.93 & 98.89 & 99.43 \\
\hline
\end{tabular}

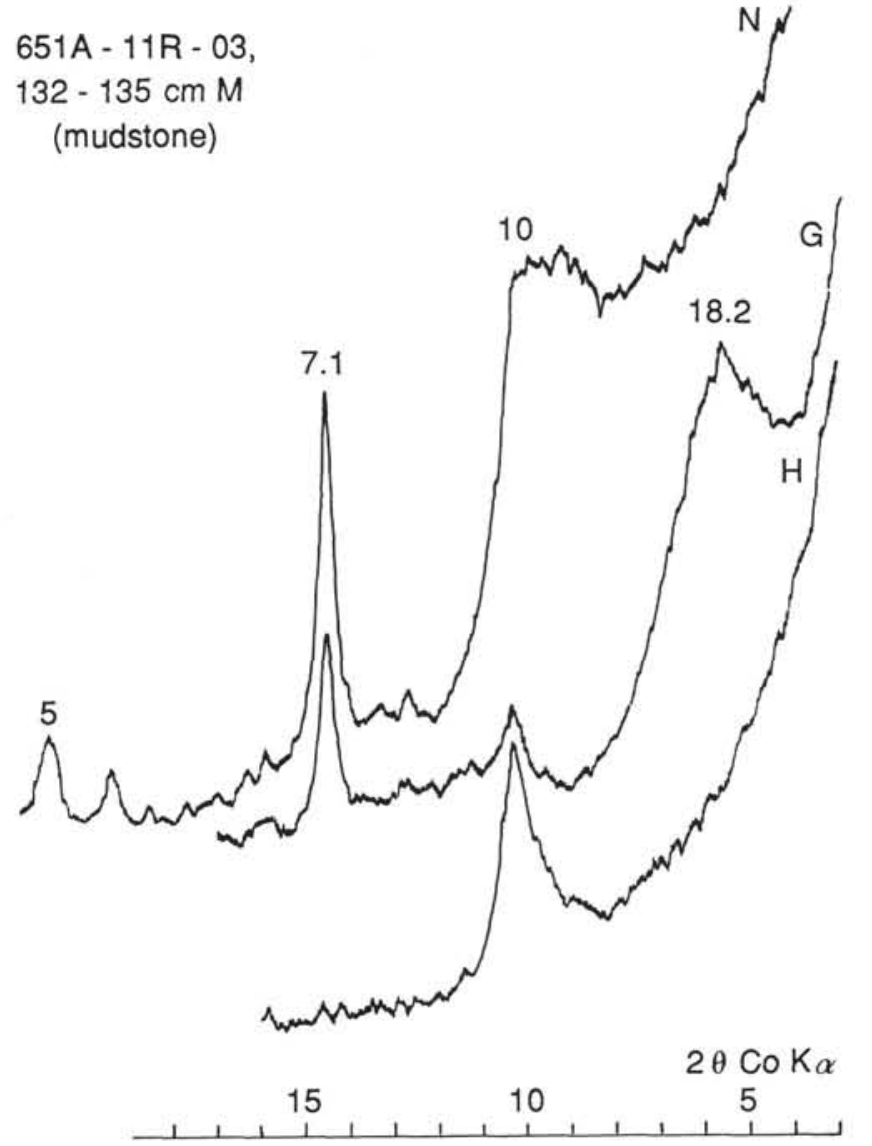

Figure 6. XR-diagrams. Mudstone. $<2-\mu \mathrm{m}$ fraction.

dicate the existence of saponite-type layers in addition to ferriferous dioctahedral structures (Brown, 1963; Desprairies, 1983) despite the $\mathrm{MgO}$ content which is only about $10 \%$ (Table 6).

The infrared investigations give some detail to this mineralogical problem (Fig. 8). Both samples give the same spectra. In the high frequencies field one observes only an absorption band at $3620-3625 \mathrm{~cm}^{-1}$ besides the strong adsorption band near $3420 \mathrm{~cm}^{-1}$ (interlayer $\mathrm{H}_{2} \mathrm{O}$ vibration). The characteristic bands of saponite or Fe saponite layers at 3550 and $3678 \mathrm{~cm}^{-1}$ (Farmer, 1974; Van der Marel and Beutelspacher, 1976; Parra et al., $1985)$ are not present. This fact and the absence, in the low frequencies field, of absorption bands at $685 \mathrm{~cm}^{-1}$ and toward 650 $\mathrm{cm}^{-1}$ shows that the smectites, for the most part or in totality, correspond to a beidellite-type mineral (Parra et al., 1985).

Thus, from the presence of two $(060)$ reflections at 1.50 $1.505 \AA$ and $1.52-1.525 \AA$, and the absence of saponite, it follows that a very large proportion or the whole of the "swelling complex" consists of Fe-Mg beidellites identical to those described by Chamley et al. (1985) (they were named $\mathrm{Mg}$ beidellites by these authors). This conclusion is corroborated by chemical analyses of the bulk purified clay fraction $(<1 \mu \mathrm{m})$ and by microchemical W.D.S. analyses of dispersed clays, seeing that measured values are close to data given by Chamley et al. (1985) (Table 6).

As stated above, it is not possible in these mudstones from Hole $651 \mathrm{~A}$ to recognize precisely authigenic phases from detrital ones because of the abundance of secondary growths. But, in view of the very large amount of $\mathrm{Fe}-\mathrm{Mg}$ beidellite, it is very likely that a part of this "swelling complex" is detrital. 

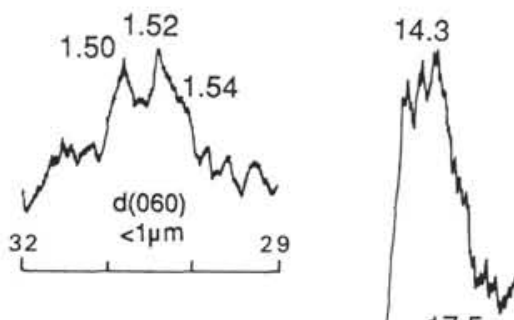

17.5

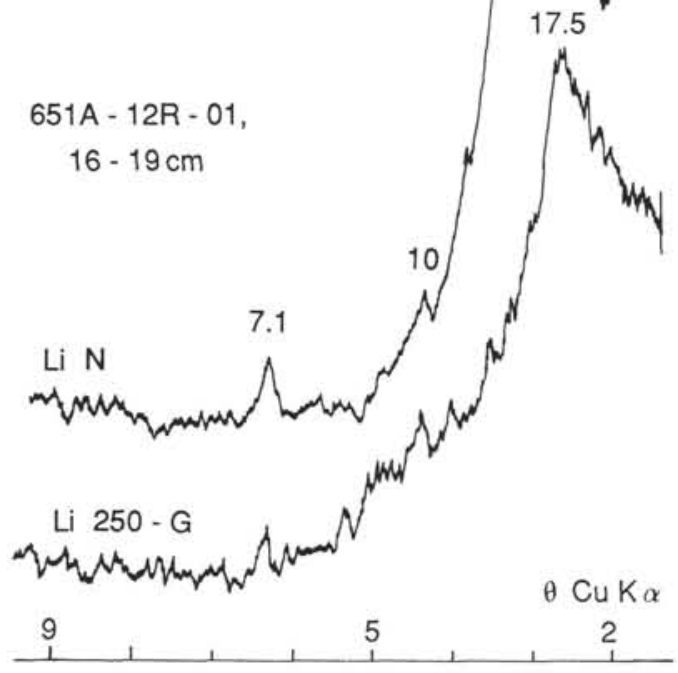

Figure 7. XR-diagrams. Clay fraction of a mudstone. Greene-Kelly's test and $\mathrm{d}(060)$ lattice dimension.
Transmission electron microscope investigations show two main morphological types of smectites:

1. The first consists of small sheets of smectites more or less transparent to the electron beam (Fig. 17, Plate 3), that resemble the "transparent smectites" of Chamley et al. (1985).

2. The second shows large opaque layers of "folded smectites" (Chamley et al., 1985) often outlined by a felting of thin elongated, curved or folded particles (Figs. 17 and 18, Plate 3). These smectites closely resemble those identified in the vicinity of the East Pacific Ridge basalts by Hoffert (1980).

These two morphological types are about equally represented. According to the microanalyses coupled with the T.E.M. observations (analyzed surface is about $0.04 \mu \mathrm{m}^{2}$ ) the composition of "transparent smectites" and "folded smectites" are not very different from each other (Table 7).

To summarize, mudstones from Hole 651A show a large development of authigenic clays, the composition of which is close to that of the primary (sedimented) smectites and would correspond to ferriferous magnesian beidellites. The morphological types of sedimented and authigenic smectites correspond to the "transparent smectites" and to the "folded smectites" of Chamley et al. (1985).

\section{DISCUSSION}

Cohesion and induration of studied samples do not result from carbonate diagenesis. Soft muds are as rich or richer in carbonate than firm muds and mudstones (Fig. 1) and S.E.M. observations do not show any pore-bridging by carbonates. Elements are not linked either by siliceous or silico-aluminous components (no visible lepispheres, very weak amounts of amorphous $\mathrm{Si}$ and $\mathrm{Al}$ extracted by selective reagents).

Table 6. Chemical composition (\%) of smectites at Hole 651A-comparison with Fe-Mg beidellites of the East Mariana Basin. (Calculated data for anhydrous composition, $10 \%-15 \% \mathrm{H}_{2} \mathrm{O}$.)

\begin{tabular}{|c|c|c|c|c|c|}
\hline & $\begin{array}{l}\text { Chemical } \\
\text { fraction }\end{array}$ & $\begin{array}{l}\text { analyses } \\
<1.0 \mu \mathrm{m}\end{array}$ & $\begin{array}{r}\text { Microp } \\
\text { analy } \\
\text { average }\end{array}$ & $\begin{array}{l}\text { robe } \\
\text { ses }\end{array}$ & $\begin{array}{l}\text { Fe-Mg beidellites } \\
\text { of the East Mariana } \\
\text { Basin }\end{array}$ \\
\hline & a & b & a & $\mathrm{b}$ & $(*)$ \\
\hline $\mathrm{SiO}_{2}$ & 56.16 & 56.01 & 54.76 & 52.96 & 53.24 \\
\hline $\mathrm{Al}_{2} \mathrm{O}_{3}$ & 14.61 & 16.94 & 14.06 & 15.58 & 17.89 \\
\hline $\mathrm{Fe}_{2} \mathrm{O}_{3}$ & 11.91 & 12.21 & 12.85 & 13.49 & 11.80 \\
\hline MnO & .08 & .07 & .15 & .13 & .10 \\
\hline $\mathrm{MgO}$ & 11.18 & 8.46 & 12.00 & 10.50 & 9.19 \\
\hline $\mathrm{CaO}$ & .18 & .12 & .54 & .38 & 1.09 \\
\hline $\mathrm{Na}_{2} \mathrm{O}$ & .36 & .12 & .39 & .32 & 1.09 \\
\hline $\mathrm{K}_{2} \mathrm{O}$ & 1.82 & 2.43 & 1.87 & 2.39 & 2.85 \\
\hline $\mathrm{TiO}_{2}$ & .10 & .12 & .33 & .43 & 1.28 \\
\hline Total & 96.40 & 96.48 & 96.95 & 96.18 & 98.53 \\
\hline
\end{tabular}




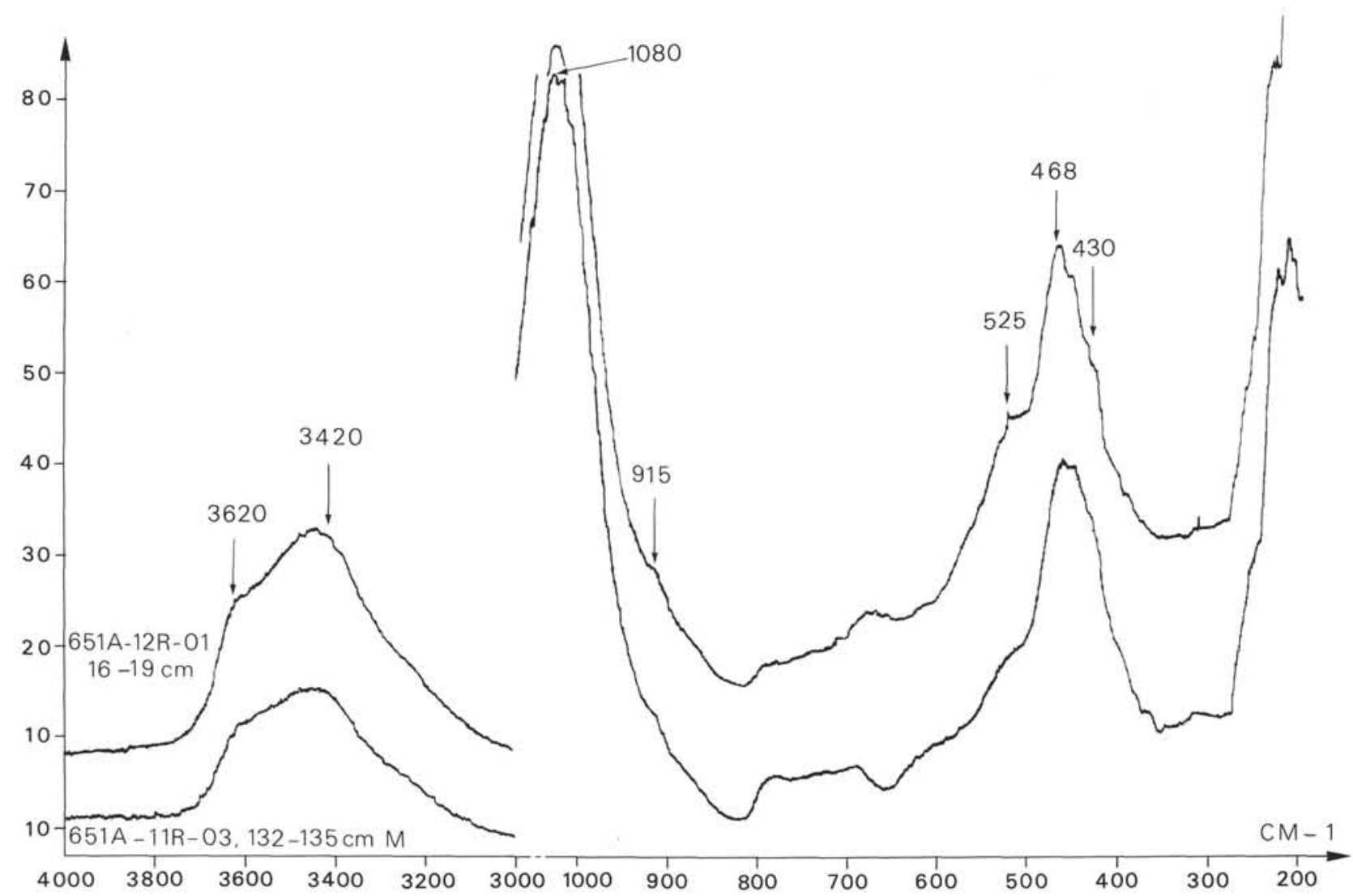

Figure 8. IR spectra of the clay fraction. Mudstones.

The cohesion of firm muds of Hole 650A and the induration of mudstones of Hole 651A appear essentially as a consequence of in situ silicate and, in particular, clay authigenesis. This diagenetic process creates secondary growths on previously sedimented particles that, finally, are linked by diagenetic bridges. It is a well known phenomenon and numerous examples of porebridging by smectites (and other clay minerals) have been shown by Welton (1984). Figures 1-3, Plate 1, and Figures 11-15, Plates 2 and 3, give evidence of a gradual increase in the proportion of secondary authigenic clays, resulting in a gradual loss of porosity and leading to changes from soft muds to firm muds and finally to mudstones.
Zeolites appear to contribute to the induration phenomenon only in the Samples $651 \mathrm{~A}-11 \mathrm{R}-3,132-135 \mathrm{~cm}$ (mudstone and sandstone), and $651 \mathrm{~A}-12 \mathrm{R}-1,16-19 \mathrm{~cm}$. But, even in these samples, phillipsite crystals seem to play a moderate role as a cement, because of their very preferential localization in intra-element pores and as a rim around interspersed clastic particles.

Smectites may directly precipitate from hydrothermal fluids (cf. synthesis in Cole and Shaw, 1983). But, in the case of the studied samples, this hypothesis must be ruled out. The two Sites $650 \mathrm{~A}$ and $651 \mathrm{~A}$ are not in a marginal position within the Marsili and Vavilov basins and the occurrence of an intrusive body in the Pleistocene sediment column has not been signaled

Table 7. Semiquantitative E.D.S. microanalyses of "transparent smectites" and "folded smectites" (Sample 651A11R-3, 132-135 cm, mudstone part).

\begin{tabular}{|c|c|c|c|c|c|c|c|}
\hline \multicolumn{4}{|c|}{$\begin{array}{l}\text { "Transparent smectites" } \\
\text { count up : } 538 \mathrm{sec} .\end{array}$} & \multicolumn{4}{|c|}{$\begin{array}{l}\text { "Folded smectites" } \\
\text { count up : } 470 \mathrm{sec} .\end{array}$} \\
\hline Si & 267825 shots & $\mathrm{Si} / \mathrm{Al}=$ & $=3.61$ & $\mathrm{Si}$ & 351734 shots & $\mathrm{SI} / \mathrm{AI}=$ & 4.31 \\
\hline Al & 74152 & $\mathrm{Si} / \mathrm{Fe}=$ & $=4.28$ & Al & 81433 & $\mathrm{Si} / \mathrm{Fe}=$ & 3.86 \\
\hline $\mathrm{Fe}$ & 62529 & $\mathrm{Si} / \mathrm{Mg}=$ & $=5.35$ & $\mathrm{Fe}$ & 91030 & $\mathrm{Si} / \mathrm{Mg}=$ & 5.79 \\
\hline $\mathrm{Mg}$ & 50014 & $\mathrm{Si} / \mathrm{K}=$ & $=10.16$ & $\mathrm{Mg}$ & 60691 & $\mathrm{Si} / \mathrm{K}=$ & 10.55 \\
\hline $\mathrm{Ca}$ & 12086 & $\mathrm{Al} / \mathrm{Mg}=$ & $=1.48$ & $\mathrm{Ca}$ & 15432 & $\mathrm{Al} / \mathrm{Mg}=$ & 1.34 \\
\hline K & 26351 & & & K & 28019 & & \\
\hline $\mathrm{Ti}$ & 7033 & & & $\mathrm{Ti}$ & 8079 & & \\
\hline
\end{tabular}


in the vicinity of Sites 650 and 651 (Kastens, Mascle, et al., 1987, 1988). Silicate diagenesis could otherwise hardly result from convective flow of heated marine connate fluids, because studied samples are localized at about $290 \mathrm{~m}$ (Hole 651) and 200 or $470 \mathrm{~m}$ (Hole 650 ) above the volcanic basement, and no fault serving as a fluid pathway has been signaled in this area (Kastens, Mascle, et al., 1987, 1988).

Neither is a low temperature combination of Fe-oxyhydroxides and biogenic silica as discussed by Chamley and Millot (1972); Dymond and Eklund (1978); Hoffert (1980) and others (cf. synthesis in Cole and Shaw, 1983) very plausible. Despite the detailed techniques used, we did not find significant siliceous biogenic debris. High productivity of siliceous microorganisms, such as would serve as a source for the large amount of Si necessary for $2 / 1$ clay genesis, does not appear commonly in the Mediterranean Sea. Such blooms as for instance in the Santorin Caldera (Chamley and Millot, 1972) or in a small basin located on the eastern slope of the Tyrrhenian Sea, in the most internal, presently submerged, portion of southern Apennines (Castellarin and Sartori, 1978), seem to be local. Moreover, the smectites crystallizing from alteration of biogenic silica would correspond to iron-rich beidellites (nontronite) or Fe-montmorillonites (Dymond and Eklund, 1978; Hein et al., 1979; Cole and Shaw, 1983), clay mineral forms different from those recognized in the samples studied.

From the previous lines of evidence and from the large amount of volcanogenic material in the cores of Holes 650A and 651A (Shipboard Scientific Party in Kastens, Mascle, et al., 1987 ) it is possible to infer that authigenesis of clays have resulted mainly from in situ low temperature alteration of volcaniclastic particles. According to downhole temperature measurements or geothermal gradients (Shipboard Scientific Party in Kastens, Mascle, et al., 1987), temperature is currently about $25^{\circ}-30^{\circ} \mathrm{C}$ at the depths of sampling for both Holes $650 \mathrm{~A}$ and $651 \mathrm{~A}$. So, it may be assumed that ambient temperature of these sediments deposited at about $200 \mathrm{~m}, 300 \mathrm{~m}$, or $470 \mathrm{~m}$ above the volcanic basement was also below $50^{\circ} \mathrm{C}$ during their diagenesis. Chamley and Giroud d'Argoud (1978), however, studied Leg $42 \mathrm{~A}$ samples and concluded that the transformation of volcanogenic material to clay minerals is not common in volcaniclastic sediments of the Mediterranean Sea. Actually, andesitic and dacitic volcanic glasses of Sample $650 \mathrm{~A}-18 \mathrm{X}-1,95-96 \mathrm{~cm}$, for instance, do not contain evidence of alteration, and increase of volcanogenic material corresponds to a significant reduction in the proportion of clays (Fig. 1). But, considering the composition and the size of parental volcanogenic elements as discussed below, there may exist no contradiction between the proposed hypothesis and these previous observations on the sediments of the Mediterranean Sea.

Samples of Hole 651A show that the sediments of indurated sections were enriched with small particles of basaltic composition (microlitic lavas and palagonitized glass), the susceptibility to alteration of which results from their composition and small size. Thus, it is understandable that these sediments show authigenic mineralogical growths, whereas layers containing more siliceous ashes or glasses, like those interbedded in common deepsea sediments of the Mediterranean Sea, and similar to the ones considered by Chamley and Giroud d'Argoud (1978) "rarely show any characteristic authigenic clay mineral growth" (Chamley and Giroud d'Argoud, 1978).

For samples of Hole $650 \mathrm{~A}$, it is not possible to assert definitely that the formation of authigenic clay minerals results mainly from alteration of grains of basaltic composition because the latter remain markedly subordinate with respect to more siliceous volcaniclastic and siliciclastic grains. Although volcanogenic grains and plagioclase appear essentially fresh, it is theoretically possible, considering their high percentage of sediments, that they could provide ions necessary for clay authigenesis. However, the latter hypothesis does not fit in well with the localization of firm muds in particular intervals, since volcaniclastics are abundant throughout Core $18 \mathrm{X}$ for instance. Here also, the same process as in Hole 651A appears the most plausible hypothesis since it is supported by indirect evidences as indicated below.

An in situ low temperature alteration of basaltic particles as the main source of clay authigenesis is substantiated by several arguments both for samples from Hole $650 \mathrm{~A}$ and for samples from Hole 651A:

1. At Holes $650 \mathrm{~A}$ and $651 \mathrm{~A}$, layers of indurated sediments are generally well correlated with peaks of $\mathrm{Ca} / \mathrm{Mg}$ ratio of the interstitial water. $\mathrm{Mg}$ is depleted whereas $\mathrm{Ca}$ is enriched (Kastens, Mascle, et al., 1987, p. 317). This type of geochemical modification, frequently observed in DSDP Sites, has been attributed to low temperature diagenesis by many authors (Desprairies, 1981, and references therein). In mudstones rich in basic volcanic material studied by Desprairies (Leg 60, Mariana Trough and Trench), the $\mathrm{Ca} / \mathrm{Mg}$ gradient expresses the low temperature alteration of volcanic material and authigenesis of $\mathrm{Mg}$ enriched smectites.

2. Mudstones from Holes 651A and firm muds from Hole $650 \mathrm{~A}$ contain morphological types of smectites that denote volcanic influences (Hoffert, 1980; Chamley et al., 1985).

3. Ferriferous and magnesian beidellites, like those in Hole $651 \mathrm{~A}$, have been commonly noted in sedimentary environments located in the vicinity of submarine basaltic outcrops which supply erosion or alteration materials (Hoffert, 1980; Desprairies, 1981; Chamley et al., 1985). The magnesian smectites (saponite) are commonly the result of submarine alteration of basaltic lavas (Kurnosov, 1982). Thus, ferriferous and magnesian beidellites may be the result or re-equilibration of magnesian smectites in a marine environment, with loss of $\mathrm{Mg}$ and gain of $\mathrm{Fe}$ and $\mathrm{K}$ (Hoffert, 1980). But they may also correspond to a transition towards a chloritic structure (Chamley et al., 1985). Concerning the potassic-ferriferous beidellites from Hole $650 \mathrm{~A}$, a part of them might have resulted from re-equilibration, on the seafloor, of detrital smectites derived from the continent but, a large proportion of this mineral most likely represents the endmember equilibrium phase of a submarine transformation of the Fe, Mg smectites (Parra et al., 1985). The affinity for $\mathrm{K}$ of the dioctahedral smectites with replacement in the tetrahedral layer explains their enrichment with regards to this element (RicoGamboa, 1984).

At Hole $651 \mathrm{~A}$, the proportion of land-derived terrigenous material is low. Very likely, sediments, in particular fragments of basaltic rocks, originated mainly from the slopes of the Vavilov seamount located about $20 \mathrm{~km}$ south of Hole 651A. The Vavilov seamount corresponds to an imposing volcanic complex consisting of a series of thick basaltic pillow lava flows and, according to the petrographic study of some samples, glassy altered cortex and vitreous to hyalocrystalline zones surrounding fresh-looking vesicular basalt were found (Robin et al., 1987). Also reported was a breccia composed of basaltic clasts (Robin et al., 1987). Basalts of this volcano, the upper part of which is late Pleistocene, fall into the mildly alkaline series (Robin et al., 1987).

At Hole $650 \mathrm{~A}$, the geographic origin of basic volcanogenic material is more difficult to determine. The distance between the Vavilov volcano and Hole $650 \mathrm{~A}$ (about $120 \mathrm{~km}$ ) could explain the more aluminous and potassic composition of beidellite and the larger proportion of terrigenous material. The Marsili volcano is closer to Hole $650 \mathrm{~A}$ (about $35 \mathrm{~km}$ to the east); it comprises tholeiitic basalts (Kastens et al., 1986) overlaid with 
alkaline basalts (Selli et al., 1977; Colantoni et al., 1981) and is therefore also another probable source.

Whatever the precise geographic origin of the parental material, it originated from basaltic seamounts of the Tyrrhenian Sea. Clay or clay and zeolite authigenesis, with subsequent induration, appear as an indirect consequence of inputs of this material in sediments.

Considering geochemical requirements, authigenic mineralogical growths are certainly favored by isolation of deposits with respect to seawater. Authigenic ferriferous and magnesian smectites indicate that interstitial waters are enriched in these elements. The neoformation of $2 / 1$ clays with a $\mathrm{SiO}_{2} / \mathrm{Al}_{2} \mathrm{O}_{3}$ molar ratio close to 4 , requires sufficiently rich $\mathrm{Si}$ solutions. It is known also that phillipsite can crystallize in solutions with a seawater composition (Glaccum and Boström, 1976; Stonecipher, 1976); but the occurrence of this mineral in some indurated levels may also reflects a decrease of the $\mathrm{Na} / \mathrm{K}$ ratio of interstitial solution with respect to seawater (Bernoulli et al., 1978 and references therein). The amounts of $\mathrm{K}$ required for authigenesis of phillipsite were probably delivered in situ by altered basic volcanogenic fragments enriched in this element (Hart, 1970; Melson and Thompson, 1973; Seyfried and Bischoff, 1979; Staudigel and Hart, 1983). In the same manner, the induration of Eocene volcano-sedimentary deposits from the South Pacific was explained by their isolation from seawater (Hoffert et al., 1978; Hoffert, 1980).

\section{CONCLUSION}

At Holes 650A and 651A, Pleistocene sediments consisting of turbiditic inputs rich in variable volcaniclastics interbedded with hemipelagic deposits contain some indurated layers. They are firm muds (Hole 650A) and mudstones (Hole 651A) located about $200 \mathrm{~m}$ and $470 \mathrm{~m}$ or $290 \mathrm{~m}$, respectively, above the volcanic basement. The cohesion is mainly due to authigenic smectites forming secondary growths and diagenetic bridges between grains. Phillipsite contributes to cementation only in mudstones of Hole 651A but, even in these samples, it plays only a subordinate role in the induration phenomenon. The authigenic smectites are ferriferous and magnesian beidellites in the mudstones from Hole 651A and potassic ferriferous beidellites in the firm muds from Hole $650 \mathrm{~A}$. They have approximately the same composition as the sedimented smectites.

In samples of Hole $651 \mathrm{~A}$, authigenesis of clays appears to have resulted from low temperature in situ alteration of fine basaltic material (lavas detritus and palagonitized glass) concentrated in the upper part of graded turbidite layers. These volcaniclastics have been generated by the Vavilov Seamount made up of basalts with tholeiitic affinity. In samples of Hole 650A, although less evident, the source of clay authigenesis may be also basaltic clasts originated either from the Vavilov or from the Marsili seamounts made up of tholeiitic to alkaline basalts.

The induration phenomenon appears as an indirect consequence of an increase in the contribution of intrabasinal material to volcaniclastic sedimentation in the area of Sites 650 and 651.

Also probably promoting authigenic mineralogical growths, was a relative isolation from the seawater chemical environment.

\section{ACKNOWLEDGMENTS}

The authors wish to acknowledge J. Rouiller, G. Burtin, and J. M. Portal (Centre de Pédologie Biologique, C.N.R.S., Vandoeuvre-lésNancy), G. Even (Université de Nancy 1) and F. L'hote (Centre de Recherches Pétrographiques et Géochimiques, C.N.R.S., Vandoeuvre-lésNancy) for their technical assistance.

We express appreciation to H. Chamley, F. L'hote, and J. Lucas for helpful discussion and suggestions. We gratefully thank also Drs. M. Kastner, J. Mascle, and F. McCoy for their critical review of this contribution, useful comments, and improvements in the manuscript.
Work was pro parte founded thanks to A.S.P.-C.N.R.S.-O.D.P. France.

\section{REFERENCES}

Allouc, J., 1986. Les encroûtements sous-marins de Méditerranée orientale. Une explication génétique. Rev. Inst. Fr. Pétrole, 41:351-376.

Bernoulli, D., Garrison R. E., and McKenzie, J., 1978. Petrology, isotope geochemistry, and origin of dolomite and limestone associated with basaltic breccia, Hole 373A, Tyrrhenian Sea. In Hsü, K., Montadert, L., et al., Init. Repts. DSDP, 42 (Pt. 1): Washington (U.S. Govt. Printing Office), 541-558.

Bernoulli, D., Garrison, R. E., and Mélières, F., 1978. Phillipsite cementation in a foraminiferal sandstone at Hole $373 \mathrm{~A}$ and "The case of Violated Foram." In Hsü, K., Montadert, L., et al., Init. Repts. DSDP 42 (Pt. 1): Washington (U.S. Govt. Printing Office), 478482.

Biscaye, P. E., 1965. Mineralogy and sedimentation of recent deep-sea clay in the Atlantic ocean and adjacent seas and oceans. Geol. Soc. Am. Bull., 76:803-832.

Brown, G., 1963. The X-ray identification and crystal structures of clay minerals. London (Mineralogical Society), $544 \mathrm{p}$.

Castellarin, A., and Sartori, R., 1978. Quaternary iron-manganese deposits and associated pelagic sediments (radiolarian clay and chert, gypsiferous mud) from the Tyrrhenian Sea. Sedimentology, 25:801821 .

Chamley, H., 1969. Intérêt de l'étude chiffrée des minéraux argileux par diffraction des rayons $\mathrm{X}$ pour la connaissance des paléoclimats. Exemple des sédiments de Méditerranée nord-occidentale. Colloque sur les méthodes analytiques par rayonnements X, Montpellier, 1969, C.G.R., compte rendu des séances: 99-106.

Chamley, H., Coulon, H., Debrabant, P., and Holtzapffel, T., 1985. Cretaceous interactions between volcanism and sedimentation in the East Mariana Basin, from mineralogical, micromorphological, and geochemical investigations (Site 585, Deep Sea Drilling Project). In Moberly, R., Schlanger, S.O., et al., Init. Repts. DSDP, 89. Washington (U. S. Govt. Printing Office), 413-429.

Chamley, H., and Giroud D'Argoud, G., 1978. Clay mineralogy in volcanogenic sediments. In Hsü, K., Montadert, L., et al., Init. Repts. DSDP, 42 (Pt. 1): Washington (U. S. Govt. Printing Office), 395397.

Chamley, H., and Millot, G., 1972. Néoformation de montmorillonite à partir de diatomées et de cendres dans les sédiments marins de Santorin (Méditerranée orientale). C. R. Acad. Sci., Paris, Ser. D, 274: 1132-1134.

Colantoni, P., Fabbri, A., Gallignani, P., Sartori, R., Rehault, J. P., 1981. Carta lithologica e stratigraphica del Mari Italiano. C.N.R. e Institut per la Geologia Marina, Bologna, Litografica Artistica cartografica, Firenze.

Cole, T. G., and Shaw, H. F., 1983. The nature and origin of authigenic smectites in some recent marine sediments. Clay Minerals, 18:239252.

Desprairies, A., 1981. Authigenic minerals in volcanogenic sediments cored during Deep Sea Drilling Project Leg 60. In Hussong, D. M., Uyeda, S., et al., Init. Repts. DSDP, 60. Washington (U.S. Govt. Printing Office), 455-466.

1983. Relation entre le paramètre b des smectites et leur contenu en fer et magnésium. Application a l'étude des sediments. Clay Minerals, 18:165-175.

Dymond, J., and Eklund, W., 1978. A microprobe study of metalliferous sediment components. Earth Planet. Sci. Lett., 40:243-251.

Elverhøi, A., and Rønningsland, T. M., 1978. Semiquantitative calculation of the relative amounts of kaolinite and chlorite by X-ray diffraction. Mar. Geol., 27:M19-M23.

Farmer, V. C., 1968. Infrared spectroscopy in the clay mineral studies. Clay Minerals, 7:373-387.

1974. The layer silicates. In Farmer, V. C. (Ed.), The Infrared Spectra of Minerals. London (Mineralogical Society), 331-363.

Fey, M. V., and Leroux, J., 1975. Quantitative determination of Allophane in Soil Clays. Proc. Internat. Clay Conf. Wilmette, IL (Applied Publishing Ltd.), 451-463.

Garrison, R. E., 1981. Diagenesis of oceanic carbonate sediments: a review of the DSDP perspective: In Warme, J. E. (Ed.) The Deep Sea Drilling Project: a decade of progress. SEPM Spec. Publ., 32:181207. 
Glaccum, R., Boström, K., 1976. (Na,K)-Phillipsite: its stability conditions and geochemical role in the deep sea. Mar. Geol., 21:47-58.

Greene-Kelly, R., 1953. The identification of montmorillonids in clays. J. Soil Sci., 4:233-237.

Grim, R. E. and Vernet, J. P., 1961. Etude par diffraction de vases méditerranéennes. Schweiz. Miner. Petr. Mitt., 41:65-70.

Hart, R., 1970. Chemical exchange between sea water and deep ocean basalts. Earth Planet. Sci. Lett., 9:269-279.

Hein, J. R., and Scholl, D. W., 1978. Diagenesis and distribution of Late Cenozoic volcanic sediment in the southern Bering Sea. Geol. Soc. Am. Bull., 89:197-210.

Hein, J. R., Yeh, H. W., and Alexander, E., 1979. Origin of iron-rich montmorillonite from the manganese nodule belt of the North Equatorial Pacific. Clays Clay Miner., 27:185-194.

Hoffert, M., 1980. Les "Argiles rouges des grands fonds" dans le Pacifique Centre-Est. Authigenèse, transport, diagenèse. Sci. Geol. Mém., 61:1-231.

Hoffert, M., Karpoff, A. M., Claver, N., Schaaf, A., Courtois, C., and Pautot, G., 1978. Néoformations et altérations dans trois faciès volcanosédimentaires du Pacifique Sud. Oceanolog. Acta, 2:187-202.

Jeanroy, E., 1972. Analyse totale des silicates naturels par spectrophotométrie d'absorption atomique. Chim. analyt., 54:159-166.

1983. Diagnostic des formes du fer dans les pédogeneses tempérées. Evaluation par les réactifs chimiques d'extraction et apports de la spectrométrie Mössbauer [Thèse]. Université Nancy.

Kastens, K., Mascle, J., Auroux, C., Bonatti, E., Broglia, C., Channel, J., Pietro, C., Emeis, K. C., Glaçon, G., Hasegawa, S., Hieke, W., and Mascle, G., 1986. La campagne 107 du Joides Resolution (Ocean Drilling Program) en mer Tyrrhenienne: premiers résultats. C. $R$. Acad. Sci., Paris, Sér. 2, 303:391-396.

Kastens, K. A., Mascle, J., et al., 1987. Proc. ODP, Init. Repts., 107: College Station, TX (Ocean Drilling Program).

Kastens, K., Mascle, J., Auroux, C., et al., 1988. ODP Leg 107 in the Tyrrhenian Sea: Insights into passive margin and back-arc basin evolution. Geol. Soc. Am. Bull., 100:1140-1156.

Kurnosov, V. B., Kholodokevitch, I. V., Kokorina, L. P., Kotov, N. V., and Chudaev, O. V., 1982. The origin of clay minerals in the oceanic crust revealed by natural and experimental data. Proc. Int. Clay Conf., Bologna and Pavia: Amsterdam (Elsevier), 547-556.

Mann, U., and Müller, G., 1979. X-ray mineralogy of Deep Sea Drilling Project Legs 51 through 53, Western North Atlantic. In Donnelly, T., Francheteau, J., Bryan, W., Robinson, P., Flower, M., Salisbury, M., et al., Init. Repts. DSDP, 51, 52, 53 (Pt. 2): Washington (U.S. Govt. Printing Office), 721-729.

McBirney, A., 1984. Igneous rocks. San Francisco (Freeman, Cooper), $509 \mathrm{p}$.

McKenzie, J., Bernoulli, D., and Garrison, R. E., 1978. Lithification of pelagic-hemipelagic sediments at DSDP Site 372: Oxygen isotope alteration with diagenesis. In Hsü, K., Montadert, L., et al., Init. Repts. DSDP, 42 (Pt. 1): Washington (U.S. Govt. Printing Office), 473-478.

Mehra, O. P., Jackson, M. L., 1960. Iron oxide removals from soils and clays by a dithionite-citrate system buffered with sodium bicarbonate. Clays Clay Minerals, 7:317-327.
Melson, W. G., and Thompson, G., 1973. Glassy abyssal basalts, Atlantic seafloor near St Paul's rocks: petrography and composition of secondary clay minerals. Geol. Soc. Am. Bull., 84:703-716.

Müller, G., 1961. Die rezenten Sedimente im Golf von Neapel. 2. Mineral-Neu-und-Umbildungen in den rezenten Sedimenten des Golfes von Neapel. Ein Beitrag zur Umwandlung vulkanischer Gläser durch Halmyrolyse. Beitr. Miner. Petr., 8:1-20.

Norin, E., 1953. Occurrence of authigenous illitic mica in the sediments of the central Tyrrhenian sea. Bull. Geol. Univ. Uppsala, 34:279280.

Parra, M., Delmont, P., Ferragne, A., Latouche, C., Pons, J. C., and Puechmaille, C., 1985. Origin and evolution of smectites in recent marine sediments of the NE Atlantic. Clay Minerals, 20:335-346.

Rabinowitz, P. D., Kidd, R. B., and Garrison, L. E., 1985. Shipboard scientist's handbook. ODP Tech. Note 3.

Rico-Gamboa, R., 1984. Thermodynamique de l'échange cationique dans les argiles [Thèse]. Univ. Louis Pasteur, $154 \mathrm{p}$.

Robin, C., Colantoni, P., Gennesseaux, M., and Rehault, J. P., 1987. Vavilov seamount: A mildly alkaline Quaternary volcano in the Tyrrhenian Basin. Mar. Geol., 78:125-136.

Rouiller, J., Brethes, A., Burtin, G., and Guillet, B., 1984. Fractionnement des argiles par ultracentrifugation en continu: évolution des illites en milieu podzolique. Sci. Géol. Bull., 37:319-331.

Schwertmann, U., 1964. Differenzierung der Eisenoxide des Bodens durch Extraktion mit Ammoniumoxalat-Lösung. Z. Pflanzener u. Bodens, 105:194-202.

Selli, R., Lucchini, F., Savelli, C., and Del Monte, M., 1977. Dati geologici, petrochimici e radiometrici sui vulcani centro Tirrenici. $G$. Geol., 47:221-246.

Seyfried, W. E., Jr., and Bischoff, J. L., 1979. Low temperature basalt alteration by seawater: an experimental study at $70^{\circ} \mathrm{C}$ and $150^{\circ} \mathrm{C}$. Geochim. Cosmochim. Acta, 43:1937-1947.

Shumenko, S. I., and Shimkus, K. M., 1979. Phillipsite mineralization and its relation to the pyroclastic components in the bottom sediments of the Mediterranean Sea. Oceanology, 19:308-310.

Staudigel, H., and Hart, S. R., 1983. Alteration of basaltic glass: processes and significance for the oceanic crust-seawater budget. Geochim. Cosmochim. Acta, 47:337-350.

Stonecipher, S., 1976. Origin, distribution and diagenesis of phillipsite and clinoptilolite in deep-sea sediments. Chem. Geol., 17:307-318.

Thorez, J., 1976. Practical identification of clay minerals. Dison, Belgium (Lelotte), $90 \mathrm{p}$.

Van Der Marel, H. W., and Beutelspacher, H., 1976. Atlas of IR spectroscopy of clay minerals and their admixtures. Amsterdam (Elsevier), $396 \mathrm{p}$.

Welton, J. E., 1984. SEM Petrology Atlas. Methods in Exploration Series. Tulsa (Am. Assoc. Pet. Geol.), 237 p.

Zanettin, B., 1984. Proposed new chemical classification of volcanic rocks. Episodes, 7:19-20.

Date of initial receipt: 1 December 1987

Date of acceptance: 9 December 1988

Ms 107B-122 


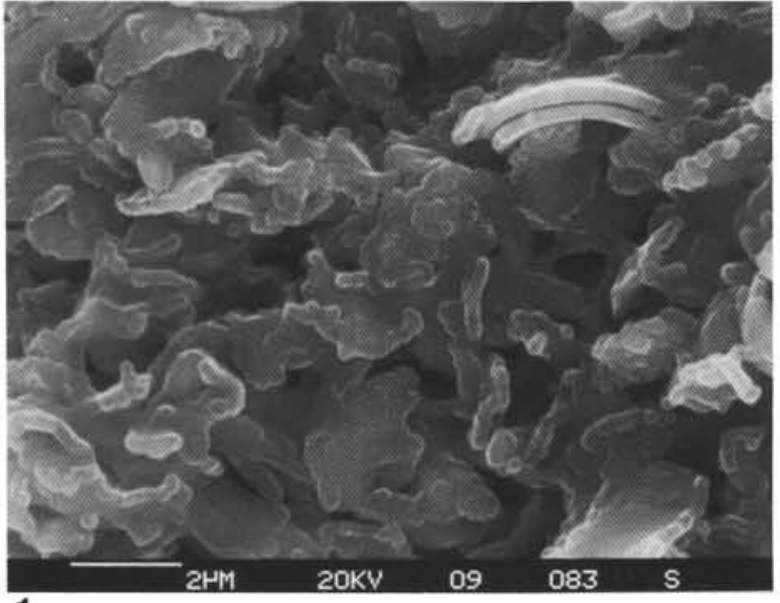

1

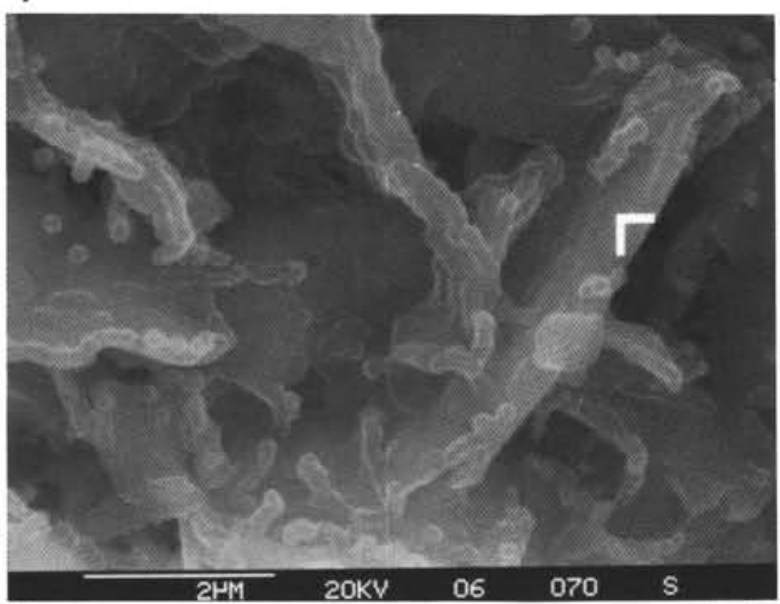

3

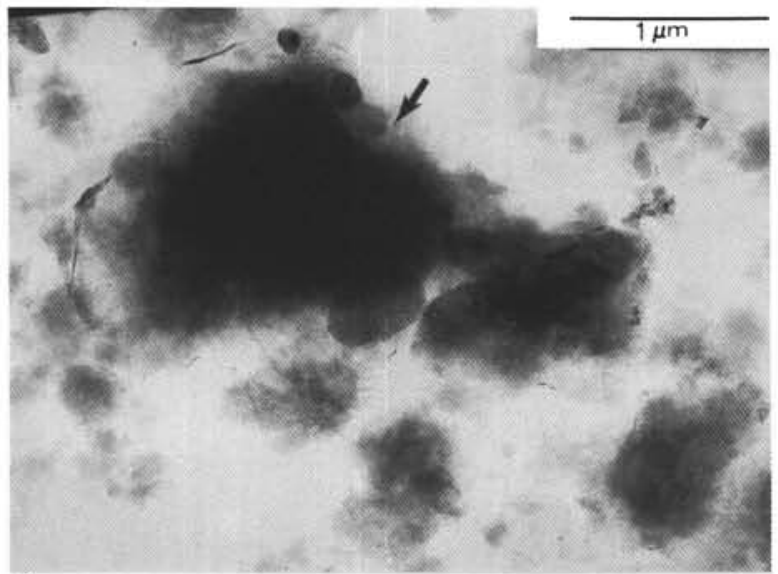

5
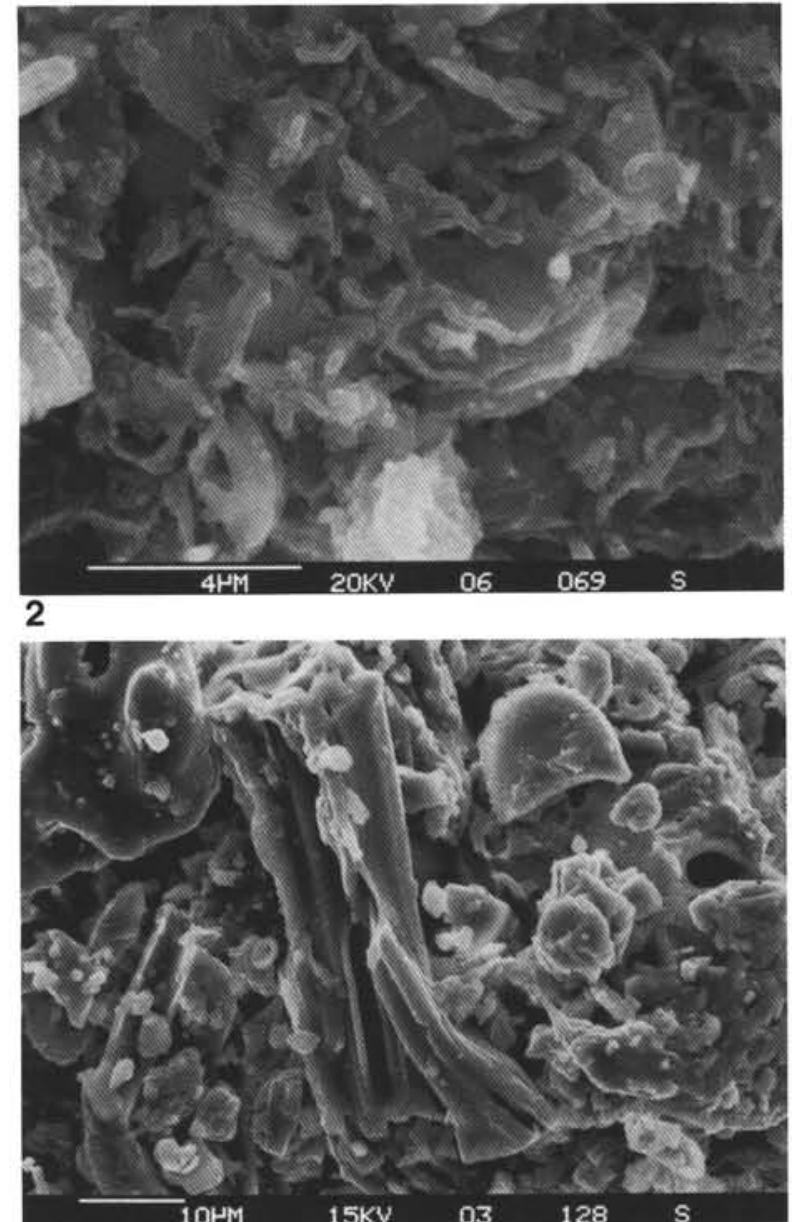

4

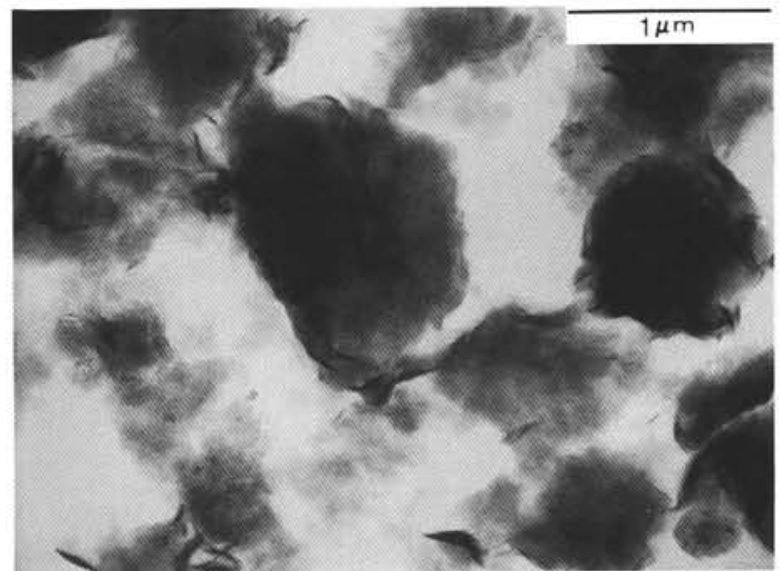

6

Plate 1. 1. Sample 650A-18X-2, 149-150 cm. Microstructure of a poorly indurated sediment. 2. Sample $650 \mathrm{~A}-18 \mathrm{X}-1$, 9-10 cm. Microstructure of a firm mud. Note the occurrence of numerous gently folded clay sheets in which the terrigenous and biogenic particles are embedded. 3. Same sample, detail. Clay sheets show numerous tiny secondary growths both on their $(001)$ faces and their edges. 4. Sample $650 \mathrm{~A}-18 \mathrm{X}-1,95-96 \mathrm{~cm}$. Volcanic glass fragments with gas tubes. The majority of these volcanogenic grains have an andesitic composition, some have approximately a dacitic composition. Note the fresh appearance of the clean elongated glassy particle in the center of the photograph. 5. Sample 650A-18X-2, 149-150 cm. TEM.

"Fleecy smectites" (arrow) almost similar to the morphological type described by Chamley et al. (1985). < 1- $\mu \mathrm{m}$ fraction. 6. Sample 650A-18X-1, 9-10 cm. Assemblage with several "folded smectites" (Chamley et al., 1985). $<0.5-\mu \mathrm{m}$ fraction. 


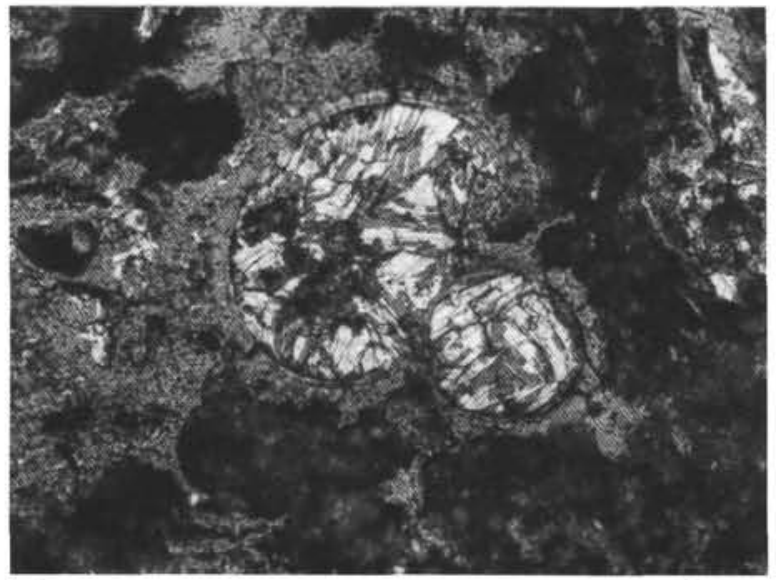

7

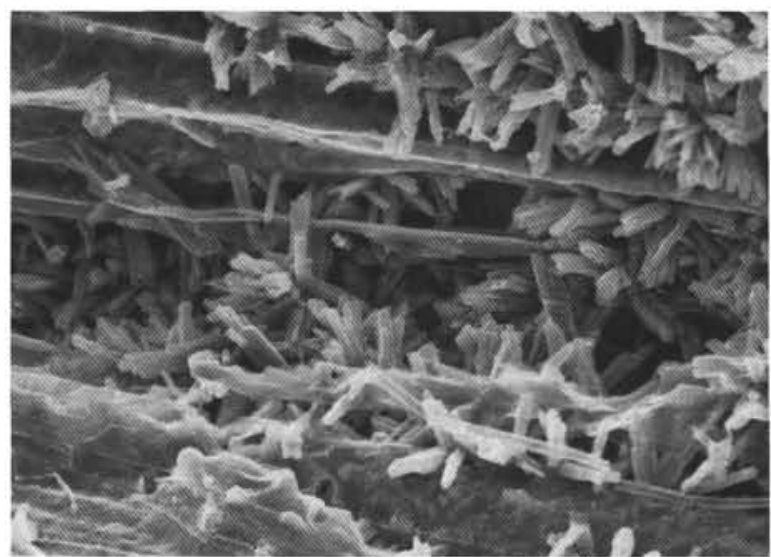

9

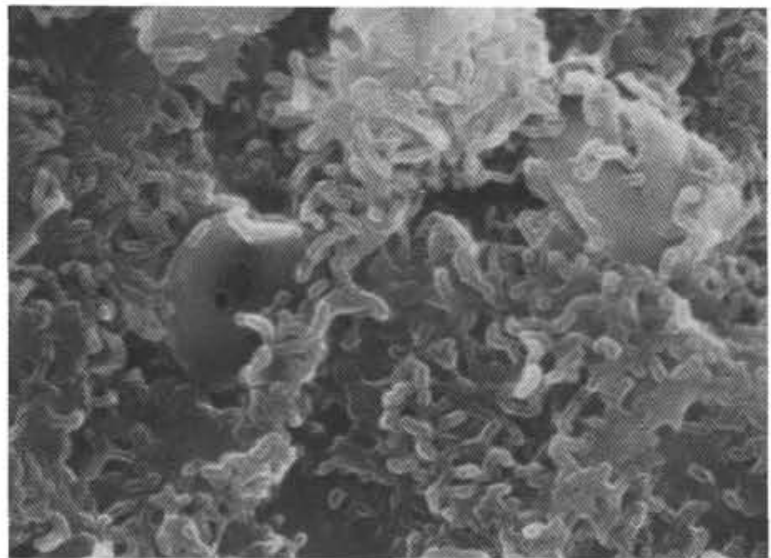

11

$2 \mu \mathrm{m}$

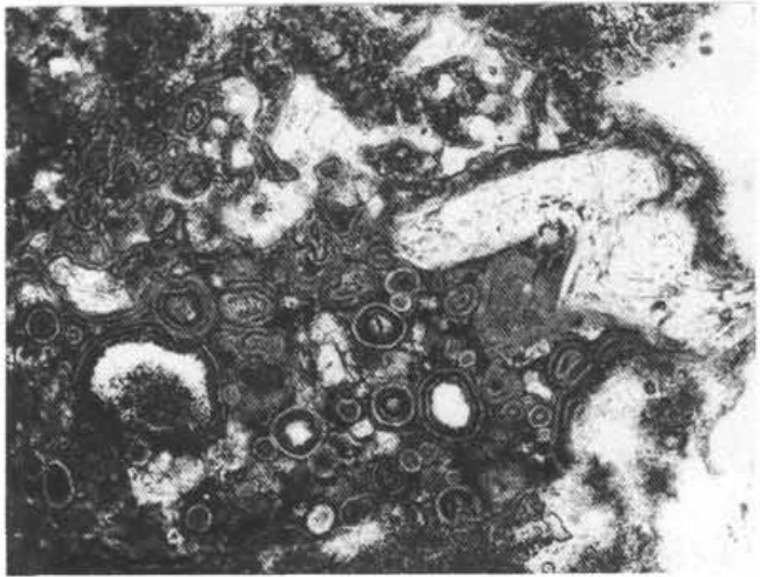

8

$100 \mu \mathrm{m}$

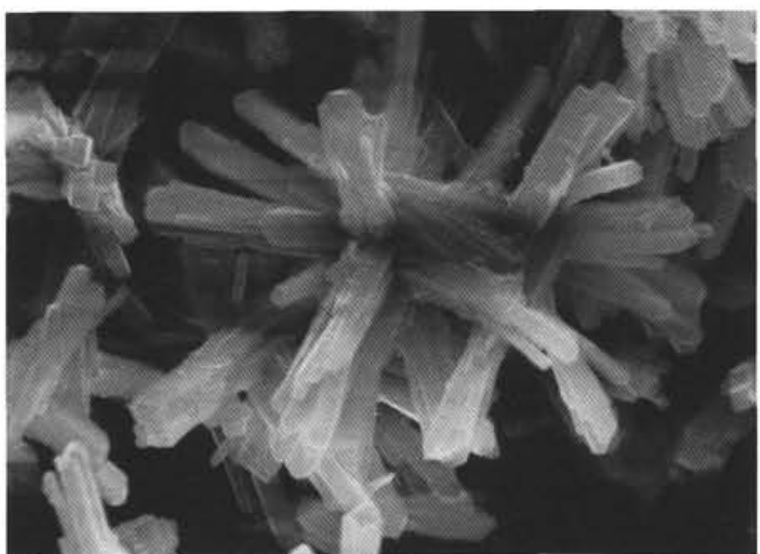

10

$10 \mu \mathrm{m}$

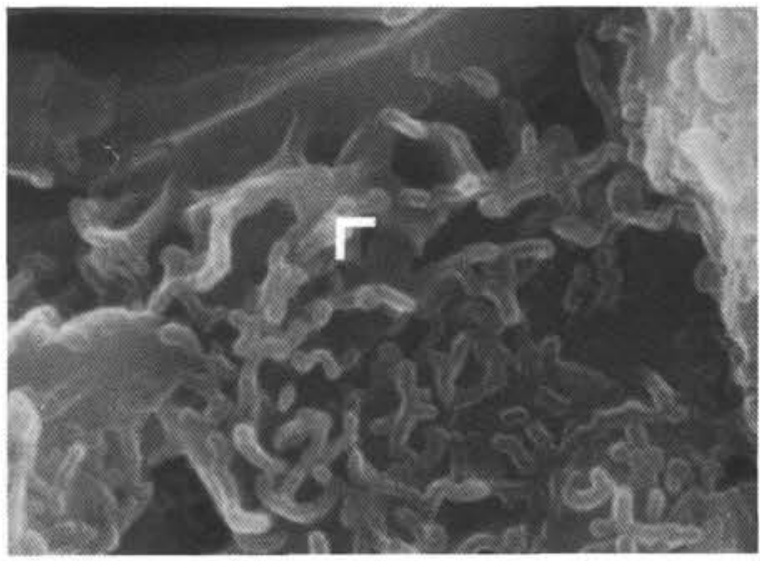

12

$1 \mu \mathrm{m}$

Plate 2. 7. Sample $651 \mathrm{~A}-12 \mathrm{R}-1,16-19 \mathrm{~cm}$. Zeolite crystals (phillipsite) in a foraminiferal chamber. 8. Sample $651 \mathrm{~A}-11 \mathrm{R}-3,132-135 \mathrm{~cm}$, sandstone part. Altered basaltic glass fragment with a vesicular structure. 9. Same sample. Authigenic pore-lining phillipsite crystals developed on a volcanogenic particle. 10. Detail of 9. Rosette of phillipsite crystals. 11. Sample $651 \mathrm{~A}-11 \mathrm{R}-3,16-19 \mathrm{~cm}$, mudstone part. Aspect of the clay material mainly composed of gently folded sheets. 12. Detail of 11 . Clay minerals appear linked to each other and form diagenetic bridges plainly visible on the side of the detrital fragment. 

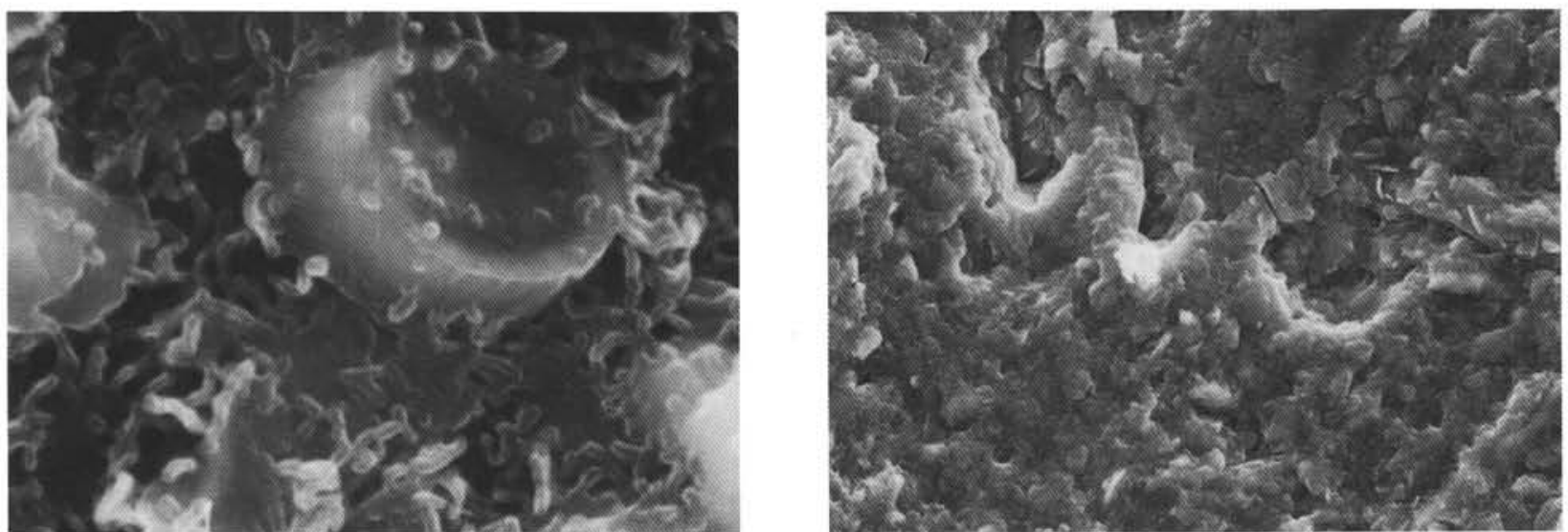

12

$2 \mu \mathrm{m}$

14

$\underline{10 \mu \mathrm{m}}$
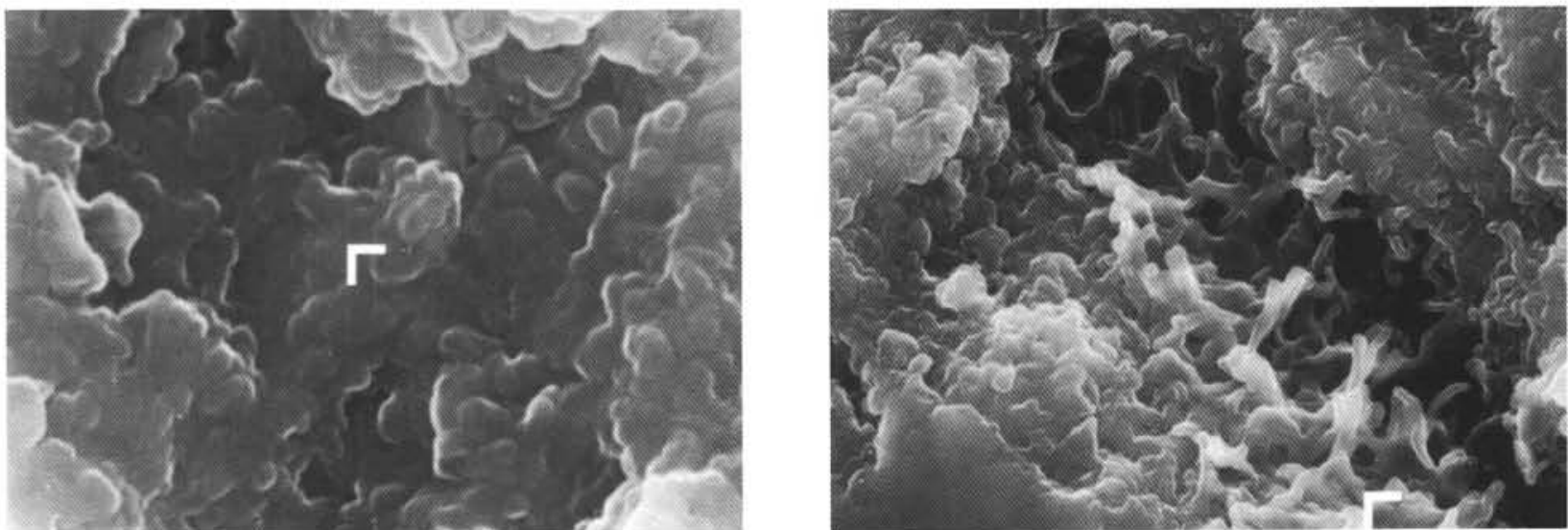

15

$1 \mu \mathrm{m}$

16

$2 \mu \mathrm{m}$
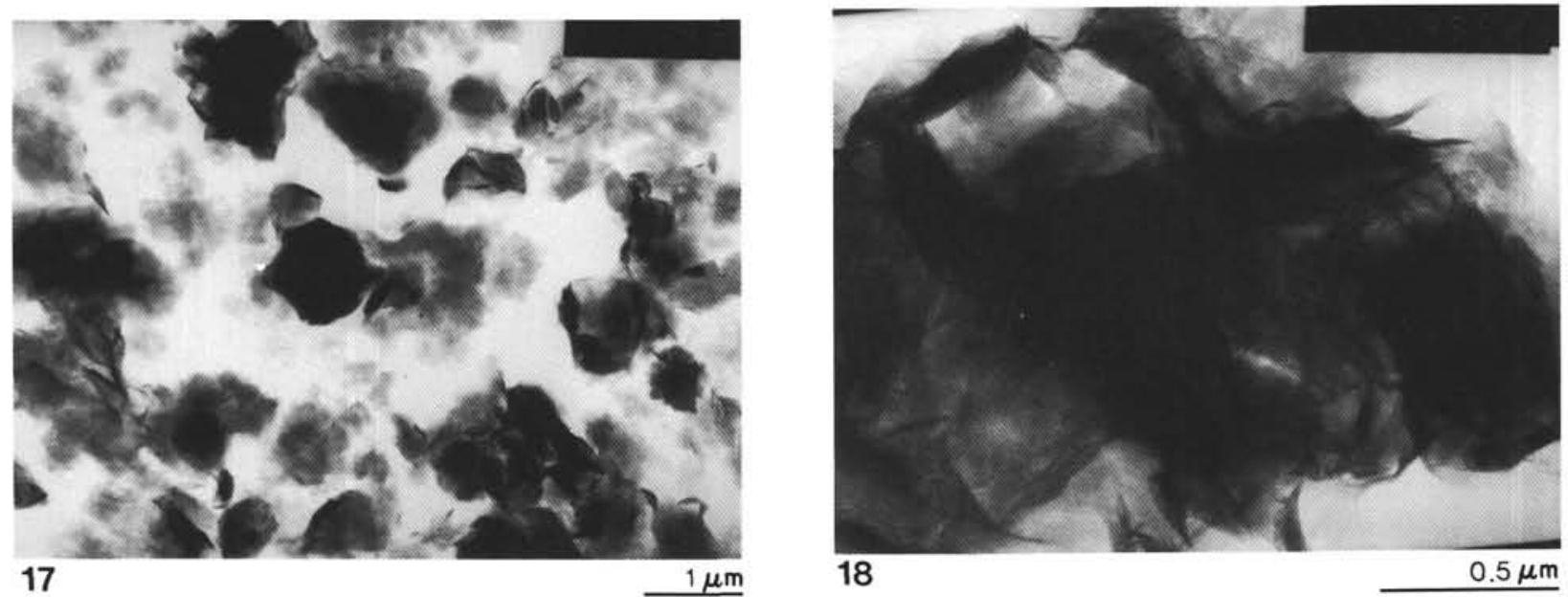

Plate 3. 13. Sample 651 A-11R-3, 132-135 cm, mudstone part. Growth of clays on a carbonated biogenic particle (probably a coccolith). 14. Sample 651A-12R-1, 16-19 cm. Homogeneous and more or less massive aspect of the microstructure. 15. Detail of 14 . 16. Same sample. Transition to a morphological clay type similar to that of Sample $651 \mathrm{~A}-11 \mathrm{R}-3,132-135 \mathrm{~cm}$, mudstone part. 17. Same sample. TEM. Clay assemblage is essentially made up of opaque "folded smectites" with some "transparent smectites." 18. Same sample. TEM. Detail of "folded smectites" constituting an aggregate. 